\title{
Taxonomic characterization of Ochrobactrum sp. isolates from soil samples and wheat roots, and description of Ochrobactrum tritici sp. nov. and Ochrobactrum grignonense sp. nov.
}

\author{
Michael Lebuhn, ${ }^{1,2}$ Wafa Achouak, ${ }^{1}$ Michael Schloter, ${ }^{2}$ \\ Odile Berge, ${ }^{1}$ Harald Meier, ${ }^{3}$ Mohamed Barakat, ${ }^{1}$ \\ Anton Hartmann ${ }^{2}$ and Thierry Heulin ${ }^{1}$
}

1 DSV-DEVM, Laboratoire d'Ecologie Microbienne de la Rhizosphère, UMR163 CNRS-CEA, CEA Cadarache, F-13108 St Paul lèz Durance, France

2,3 Institute of Soil Ecology2, and Flow Cytometry Group ${ }^{3}$, GSF - National Research Center for Environment and Health, Ingolstädter Landstr. 1, D-85764 Neuherberg, Germany
Author for correspondence: Michael Lebuhn. Tel: +49 893187 2903. Fax: +4989 31873376. e-mail: lebuhn@gsf.de

A large collection of bacterial strains, immunotrapped from soil and from the wheat rhizoplane, was subjected to polyphasic taxonomy by examining various pheno- and genotypic parameters. Strains were grouped on (inter) repetitive extragenic palindromic DNA (REP) PCR profiles at the intraspecies level. Pheno- and genotypic characters were assessed for representatives from 13 different REP groups. Strains of nine REP groups constituting two physiological BIOLOG clusters fell in the coherent DNA-DNA reassociation group of Ochrobactrum anthropi. Strains of two REP groups constituting a separate BIOLOG cluster fell in the coherent DNA-DNA reassociation group of Ochrobactrum intermedium. Additional phenotypic characters differentiating $O$. anthropi and $O$. intermedium were found. REP group $K$ strains constituted a different BIOLOG cluster, a separate DNA-DNA reassociation group and a distinct phylogenetic lineage in 165 rDNA homology analysis, indicating that REP group K strains represent a new species. Diagnostic phenotypic characters were found. Closest relatives were Ochrobactrum species. The name Ochrobactrum grignonense sp. nov. is proposed (type strain $0 \mathrm{OA99} \mathrm{a}^{\top}=\mathrm{LMG}$ $1^{18954^{\top}}$ = DSM 13338 ${ }^{\mathrm{T}}$ ). REP group J strains again constituted a different BIOLOG cluster, a separate DNA-DNA reassociation group and showed, as a biological particularity, a strict preference for the rhizoplane as habitat. Diagnostic phenotypic characters were found. This indicated that REP group J strains represent a further new species, although phylogenetic analyses using $16 \mathrm{~S}$ rDNA homology were not able to separate the cluster of REP group J sequences significantly from $16 S$ rDNA sequences of Ochrobactrum anthropi. The name

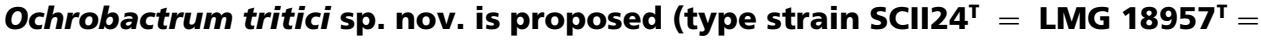
DSM 13340').

Keywords: Ochrobactrum, immunotrapping from bulk soil and wheat rhizoplane, polyphasic taxonomy, geno- and phenotyping, repetitive extragenic palindromic DNA

\section{INTRODUCTION}

The genus Ochrobactrum was described first by Holmes et al. (1988) and belongs to the $\alpha-2$ subclass of the

Abbreviations: REP, repetitive extragenic palindromic DNA; $T_{\mathrm{m}}$, melting temperature.

The GenBank/EMBL accession numbers for the $16 \mathrm{~S}$ rDNA sequences of strains CLM18, CLM14, isolate 1a, LAIII106, O. anthropi LMG 5140, OgA9a', OiC8-6, OiC8a and SCII24 ${ }^{\top}$ are AJ242576-AJ242584, respectively.
Proteobacteria (De Ley, 1992). The phylogenetic position of Ochrobactrum sp. was defined by De Ley (1992) and Yanagi \& Yamasato (1993) on the basis of DNA-rRNA hybridization and 16S rDNA homology studies. Swings et al. (1992) described the genus Ochrobactrum. Its closest known relative is Brucella (De Ley, 1992; Moreno, 1992; Yanagi \& Yamasato, 1993; Velasco et al., 1998). Moyer \& Hausler (1992) provide an overview of the genus Brucella.

Holmes et al. (1988) proposed Ochrobactrum anthropi 
Table 1. Bacterial strains investigated in this study, their origin and relevant references

\begin{tabular}{|c|c|c|}
\hline Strain* (currently valid or proposed affiliation) & Origin & Reference \\
\hline \multicolumn{3}{|l|}{ Reference strains: } \\
\hline LMG $3331^{\mathrm{T}}=$ CIP $149-70^{\mathrm{T}}$ (Ochrobactrum anthropi type strain) & Unknown & Holmes et al. (1988) \\
\hline $\begin{array}{l}\mathrm{LMG} 5140=\mathrm{LMG} 2134=\mathrm{LMG} 2320(\mathrm{t} 1)=\mathrm{NCIB} 8688 \\
\text { (Ochrobactrum anthropi) }\end{array}$ & Arsenite cattle-dip trays & Holmes et al. (1988) \\
\hline LMG $3301^{\mathrm{T}}=\mathrm{CNS} 2-75^{\mathrm{T}}$ (Ochrobactrum intermedium type strain) & Human blood & $\begin{array}{l}\text { Holmes et al. (1988), } \\
\text { Velasco et al. (1998) }\end{array}$ \\
\hline Isolate 1a (Ochrobactrum anthropi) & Soil, Germany & Schloter et al. (1996) \\
\hline \multicolumn{3}{|l|}{ Isolates originating from this study: } \\
\hline ALM4-ALM21, ALM23-ALM32 & Grignon soil A, France & This study \\
\hline $\begin{array}{l}\text { CLM5-CLM17, CLM18 (= Ochrobactrum anthropi LMG 18953), } \\
\text { CLM20-CLM28 }\end{array}$ & Grignon soil C, France & This study \\
\hline $\begin{array}{l}\text { LAI4, LAI8, LAI16, LAI20, LAI24, LAI101, LAI104-LAI110, } \\
\text { LAI114, LAI116; LAII1, LAII4, LAII7, LAII10, LAII12, LAII104, } \\
\text { LAII108, LAII110, LAII114, LAII118, LAII120; LAIII2, LAIII8, } \\
\text { LAIII10, LAIII14, LAIII101, LAIII102, LAIII104, LAIII106 } \\
\text { (= Ochrobactrum tritici sp. nov. LMG 18958 = DSM 13341), } \\
\text { LAIII108, LAIII109, LAIII111, LAIII113, LAIII115, LAIII116 }\end{array}$ & $\begin{array}{l}\text { Rhizoplane of wheat } \\
\text { (cultivar Lloyd) grown } \\
\text { in Grignon soil A, } \\
\text { France }\end{array}$ & This study \\
\hline LMA1-LMA9 & Grignon soil A, France & This study \\
\hline LMC1, LMC2 & Grignon soil C, France & This study \\
\hline OaA14-1-OaA14-7, OaA19-1, OaA19-2, OaA20-1-OaA20-6 & Grignon soil A, France & This study \\
\hline OaC6-1, OaC6-2, OaC13a, OaC13-1-OaC13-4, OaC17-1-OaC17-4 & Grignon soil C, France & This study \\
\hline $\begin{array}{l}\text { OgA9 }^{\mathrm{T}}(=\text { Ochrobactrum grignonense sp. nov. type strain } \\
\text { LMG } 18954^{\mathrm{T}}=\text { DSM 13338), OgA9c }(=\text { Ochrobactrum } \\
\text { grignonense sp. nov. LMG } 18955=\text { DSM 13339) }\end{array}$ & Grignon soil A, France & This study \\
\hline $\begin{array}{l}\text { OiC8a, OiC8b, OiC8-1-OiC8-5, OiC8-6 } \\
\text { (= Ochrobactrum intermedium LMG 18956) }\end{array}$ & Grignon soil C, France & This study \\
\hline RPSCII9 & $\begin{array}{l}\text { Rhizoplane of wheat } \\
\text { (cultivar Soissons) } \\
\text { grown in Grignon } \\
\text { soil C }\end{array}$ & This study \\
\hline $\begin{array}{l}\text { SAI1, SAI2, SAI6, SAI8, SAI12, SAI13, SAI15, SAI101, } \\
\text { SAI104, SAI105, SAI107, SAI108, SAI110, SAI113, SAI116; } \\
\text { SAII1, SAII8, SAII12, SAII16, SAII101 (= Ochrobactrum } \\
\text { anthropi LMG 18952), SAII102, SAII105, SAII107, SAII110; } \\
\text { SAIII4, SAIII5, SAIII8, SAIII16, SAIII20, SAIII101, } \\
\text { SAIII104, SAIII106, SAIII108 }\end{array}$ & $\begin{array}{l}\text { Rhizoplane of wheat } \\
\text { (cultivar Soissons) } \\
\text { grown in Grignon } \\
\text { soil A }\end{array}$ & This study \\
\hline $\begin{array}{l}\text { SCII4, SCII8, SCII10, SCII16, SCII20, SCII22, SCII24 } \\
(=\text { Ochrobactrum tritici sp. nov. type strain LMG } \\
\left.18957^{\mathrm{T}}=\text { DSM } 13340^{\mathrm{T}}\right) \text {, SCII102, SCII103, SCII105, } \\
\text { SCII108, SCII110 }\end{array}$ & $\begin{array}{l}\text { Rhizoplane of wheat } \\
\text { (cultivar Soissons) } \\
\text { grown in Grignon } \\
\text { soil C }\end{array}$ & This study \\
\hline
\end{tabular}

* CIP, Collection de l'Institut Pasteur, Paris, France; CNS, Centre National des Salmonella, Paris, France; DSMZ, German Collection of Microorganisms and Cell Cultures, Braunschweig, Germany; LMG, Laboratorium Microbiologie Gent Culture Collection, Universiteit Gent, Gent, Belgium; NCIMB, National Collection of Industrial and Marine Bacteria, Torry Research Station, Aberdeen, UK.

as the sole and type species of Ochrobactrum, but they observed heterogeneities in geno- or phenotypic characters within the tested $O$. anthropi collection. The authors described three biovariants (A, C, D) of $O$. anthropi based on phenotypic differences. The strains of biovariant $\mathrm{C}$ and three strains of biovariant $\mathrm{A}$ (including strain LMG 3301) constituted a homogeneous DNA-DNA hybridization group, and the three biovariant A strains showed DNA-DNA hybridization values of only $51 \%$ or less to $O$. anthropi type strain LMG $3331^{\mathrm{T}}$ (Holmes et al., 1988). Although this argues for the presence of different species, the authors left the respective strains with $O$. anthropi because the geno- and phenotypic groupings did not lead to consistent results.

In a recent study, Velasco et al. (1998) described a new Ochrobactrum species, Ochrobactrum intermedium, and transferred the former $O$. anthropi reference strain LMG 3301 to $O$. intermedium as the type strain. They 
renamed the former $O$. anthropi biotype A strain LMG 3306 as $O$. intermedium LMG 3306 and added three novel clinical isolates. Factors discriminating between $O$. anthropi and $O$. intermedium were their low DNADNA hybridization (Holmes et al., 1988), different Western blot profiles of SDS-PAGE-separated wholecell protein antigens and resistance of $O$. intermedium to colistin and polymyxin B (Velasco et al., 1998). Interestingly, the $16 \mathrm{~S}$ rDNA similarity of $O$. anthropi and $O$. intermedium was above $98.0 \%$ and $16 \mathrm{~S}$ rDNA similarity between both Ochrobactrum species and Brucella spp. was even higher, with values up to $99 \cdot 28 \%$ between the two genera (Velasco et al., 1998).

$O$. anthropi strains have been isolated from samples originating from different continents. Most available $O$. anthropi isolates are from human clinical specimens, particularly from immunocompromised persons. $O$. anthropi LMG 5140 has been isolated from arsenical cattle dipping fluid (Holmes et al., 1988) and is described as identical to $O$. anthropi strains LMG 2134 and LMG 2320(t1). There are some reports on the presence of $O$. anthropi in soil, on wheat roots and in internal root tissues of different plants (Aguillera et al., 1993; McInroy \& Kloepper, 1994; Sato \& Jiang, 1996), but identification was based only on phenotypic characters. $O$. intermedium LMG 3306 has been isolated from a French soil (Holmes et al., 1988) and other $O$. intermedium strains are from human blood (Velasco et al., 1998).

Different mAbs against outer membrane epitopes of $O$. anthropi isolate 1a (Table 1) from a German agricultural soil (Scheyern Experimental Station of the Forschungsverbund Agrarökosysteme München; Schloter et al., 1996) have been produced. Results from quantitative ELISA indicated that the reactive bacterial serotype was present in high numbers $\left[10^{4}-10^{6}\right.$ bacteria (g dry soil) $\left.{ }^{-1}\right]$ in soil from Scheyern (Schloter et al., 1996) and in two different French soils (Lebuhn et al., 1997) from the Grignon Experimental Station (Barriuso \& Houot, 1996). The abundance of $O$. anthropi in soils makes them an ideal tool for ecological studies on microbial diversity at different scales of taxonomic resolution and for an evaluation of exogenous influences on microbial diversity in soil. It is, however, an essential prerequisite for such studies to unambiguously identify and characterize the investigated strains at and below the species level.

The objective of the present study was to examine the identity of bacteria which were immunotrapped from Grignon bulk soil samples and from the rhizoplane of wheat plants grown in the Grignon soils, at different scales of taxonomic resolution. For this purpose, a polyphasic taxonomic approach was used, testing various phenotypic and genotypic characters of the immunotrapped strain collection. Strains belonging to two novel Ochrobactrum species were immunotrapped, Ochrobactrum tritici sp. nov. and Ochrobactrum grignonense sp. nov., and are described here.

\section{METHODS}

Soils and plants, immunotrapping and bacterial strains. Soil samples (1 g fresh wt) from two agricultural soils (soils A and C, Grignon Experimental Station, France; Barriuso \& Houot, 1996) were suspended in sodium cholate and subjected to a Retsch mill treatment. Bacteria were further removed from soil particles by stirring with Chelex 100, PEG 6000 and $\mathrm{Na}^{+} /$Amberlite resin IR-120. After centrifugation of $5 \mu \mathrm{m}$ filtrates, pellets were resuspended in PBS solution $(0 \cdot 145 \mathrm{M} \mathrm{NaCl}, 0 \cdot 15 \mathrm{M}$ sodium phosphate). Immunotrapping was carried out as outlined below using aliquots of these suspensions.

Root samples were from two wheat cultivars (Triticum aestivum L. cultivars Lloyd and Soissons) which were grown in Grignon soils A and C. Seed surfaces of the wheat cultivars were sterilized, rinsed with sterile distilled water, checked for sterility (on nutrient agar; NA) and aseptically germinated in sterile tapwater in Petri dishes. Three seedlings per cultivar were grown in two plastic tubes filled up with Grignon soils A and C and under controlled growth chamber conditions for $7 \mathrm{~d}$. The harvested root systems (except cultivar Lloyd which did not grow in soil C) were liberated from adherent soil particles by washing gently in sterile tapwater, ground four times in a mortar and suspended in $0.85 \% \mathrm{KCl}$ solution. Immunotrapping was carried out as described below using aliquots of the suspensions.

Immunotrapping was performed as previously described (Biebel et al., 1995; Schloter et al., 1995) using mAb 2.11. This antibody showed highest affinity to $O$. anthropi strains and has surface lipopolysaccharides as antigenic epitopes (M. Schloter, personal communication). Briefly, mAb 2.11 was bound to protein A-coated microtitre plates. After washing, aliquots of the soil (or root) suspensions were incubated in the wells, washed and treated with glycine $/ \mathrm{HCl}$ for antibody disruption. Three repetitions were performed in two (soil samples) or four (root samples) parallels per variant. Parallels were pooled and serial dilutions of the repetitions plated on NA Petri dishes. About 700 isolated colonies were purified on NA. A random selection of these colonies (Table 1) was examined by polyphasic taxonomy.

Table 1 shows a list of strains used in this study and their origin. Several strains that were isolated and described in this study were deposited in the LMG and DSMZ culture collections (Table 1).

\section{Genotypic characters}

(i) REP-PCR. Whole cell REP-PCR [PCR amplification of highly variable genomic regions with primers matching repetitive extragenic palindromic DNA (REP) sequences] was carried out using primers REP1R-I and REP2-I (Versalovic et al., 1994) as described by Louws et al. (1996), except that $1.5 \mathrm{U}$ Taq polymerase (GoldStar; Eurogentec) was added after the initial denaturation step. After gel electrophoresis [in $0.75 \times$ TAE buffer $(0.75 \times$ TAE is $30 \mathrm{mM}$ Tris. $\mathrm{HCl}, \quad 7.5 \mathrm{mM}$ sodium acetate, $0.75 \mathrm{mM}$ sodium EDTA)] of ethidium bromide-stained $1.5 \%$ agarose gels that had been loaded with the PCR products, REP profiles were UV-visualized, digitalized and grouped on similarity using ADOBE photoshop 4 software. REP groups were defined as distinct when they differed by the presence of at least one strong band (signature band). Subgroups of REP groups were defined when respective REP profiles differed only by the presence of weak bands and/or by band strength.

(ii) DNA base composition. Molar $\mathrm{G}+\mathrm{C}$ contents of strains OgA9a ${ }^{T}$, OgA9c, OiC8-6, LAIII106, SAI12 and SCII24 ${ }^{\mathrm{T}}$ 


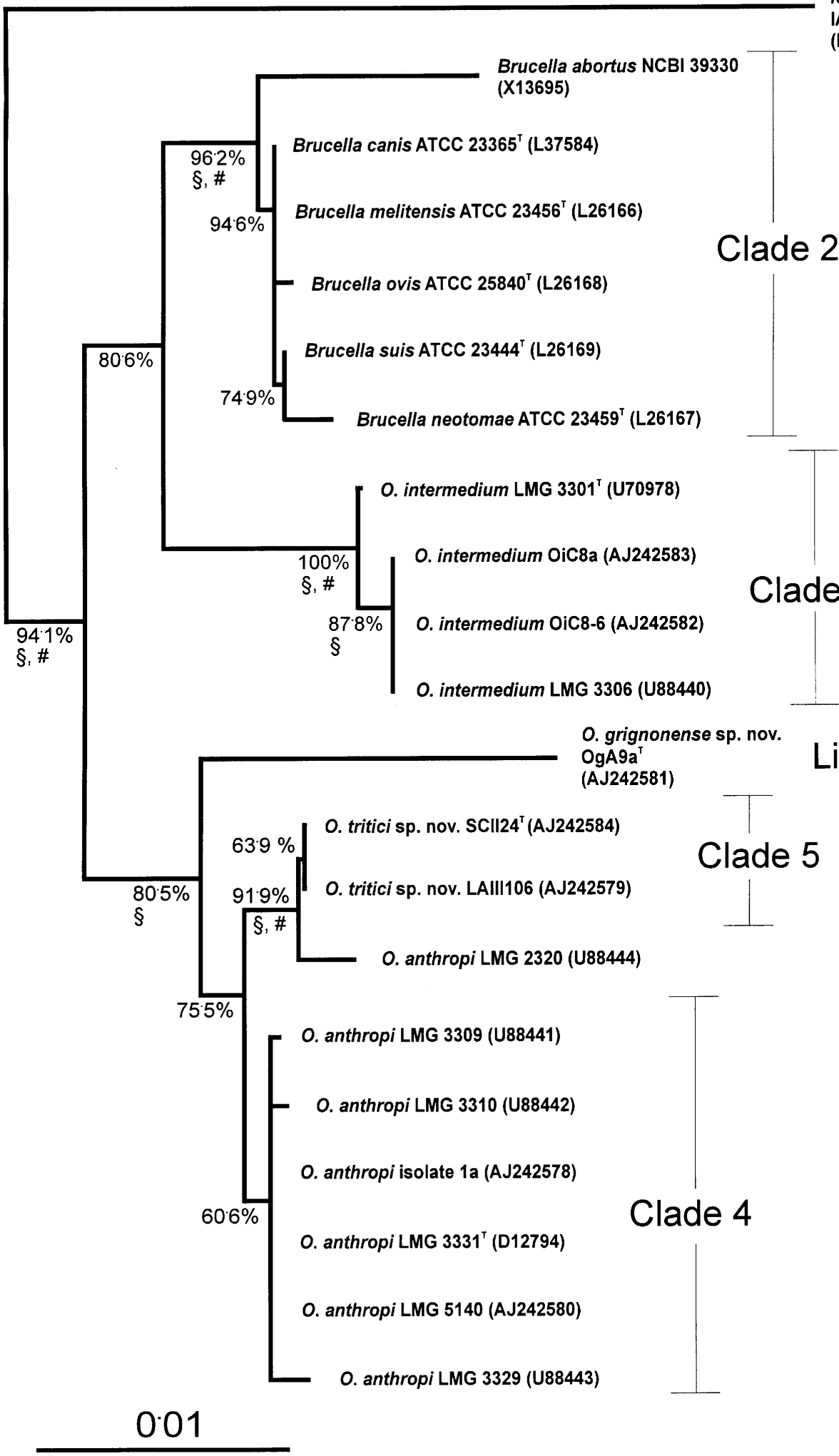

IAM $12609^{\top}$

(D14513)

Fig. 1. Phylogenetic tree of $16 \mathrm{~S}$ rDNA sequences (1292 nt) obtained using CLUSTREE neighbour-joining analysis and the Kimura two-parameter model. Bootstrap probabilities are shown in percentages of 1000 replicates. Scale bar, 0.01 divergent residues per site. Congruent topologies $(P<25 \%)$ obtained using PUZZLE maximum-likelihood and ARB maximum-parsimony analyses are shown by $\S$ and \#, respectively. The tree was rooted by outgrouping sequence D14501. 
were determined in three replications by custom service at the DSMZ, Braunschweig, Germany. In brief, DNA of French press-treated strains was purified on hydroxylapatite (Cashion et al., 1977). DNA was hydrolysed by P1 nuclease and nucleotides were dephosphorylated by alkaline phosphatase (Mesbah et al., 1989). Deoxyribonucleosides were analysed by HPLC and molar G $+\mathrm{C}$ contents were calculated by the ratio $\mathrm{dA} / \mathrm{dG}$ (Mesbah et al., 1989).

(iii) DNA-DNA hybridization and $\Delta T_{m}$ determination. DNA was extracted and purified in large scale preparation according to Brenner et al. (1982) from representative strains of the different REP groups (Table 3), until absorbance ratios $260 / 280 \mathrm{~nm}$ and $260 / 230 \mathrm{~nm}$ were at least 1.75 and $2 \cdot 1$, respectively. DNA-DNA reassociation studies were performed for at least two replicates following the $S_{1}$ nuclease TCA (trichloroacetic acid) precipitation method (Crosa et al., 1973; Grimont et al., 1980). A brief description is given as follows. Purified DNA of strains LMG 3331 ${ }^{\mathrm{T}}$, LMG 5140, SCII24 ${ }^{\mathrm{T}}$ and OiC8-6 was microdialysed and labelled with ${ }^{3} \mathrm{H}-\mathrm{dGTP}$ and ${ }^{3} \mathrm{H}-\mathrm{dCTP}$ by nick-translation. After chloroform-isoamylalcohol extraction and dialysis, ssDNA was removed by optimized $\mathrm{S}_{1}$ nuclease activity. dsDNA was extracted with chloroform-isoamylalcohol, dialysed and the radiolabel of the probes was determined. Unlabelled DNA (including a herring DNA sample to determine unspecific background label) was fragmented on ice by repeated ultrasonication pulses (Ultrasonic $250 \mathrm{TO}$; Ultrasons) to $0.4 \mathrm{~kb}$ and dialysed. Hybridization of labelled probes and unlabelled DNA was performed under stringent conditions $\left(68^{\circ} \mathrm{C}, 0.42 \mathrm{M} \mathrm{NaCl}\right)$. ssDNA was removed by $\mathrm{S}_{1}$ nuclease activity $\left(\mathrm{S}_{1}+\right)$ or not $\left(\mathrm{S}_{1}-\right)$. After TCA precipitation of DNA, the samples were briefly frozen and filtered immediately after melting. Radioactivity of the $\mathrm{S}_{1}+$ and $\mathrm{S}_{1}-$ reassociates (at least two parallels) was counted (at least six repetitions) and the specific radiolabel of dsDNA was calculated. Values for heterologous reassociation are expressed as percentages of the specific radiolabel of the corresponding homologous reassociates.

The difference between half-maximum melting temperatures of homologous and heterologous DNA reassociates $\left(\Delta T_{\mathrm{m}}\right)$ was determined according to Grimont et al. (1980) for certain strains showing heterologous reassociation values of 50-70\% (Table 3). In brief, reassociated homologous and heterologous DNA was melted at six temperatures between 68 and $100^{\circ} \mathrm{C}$. The samples were treated by $\mathrm{S}_{1}$ nuclease as described above, precipitated by TCA, filtered and the radiolabel was counted. $\Delta T_{\mathrm{m}}$ is the difference between halfmaximum homologous and heterologous $T_{\mathrm{m}}$ values.

(iv) Sequencing of $16 \mathrm{~S}$ rDNA and phylogenetic studies. $16 \mathrm{~S}$ rDNA from isolate 1a, SCII24 ${ }^{\mathrm{T}}, \mathrm{OgA} 9 \mathrm{a}^{\mathrm{T}}$, OiC8a, OiC8-6, LMG 5140, CLM14 and CLM18 was amplified by PCR using primers $\mathrm{rD} 1$ and fD1 (Weisburg et al., 1991). Amplificates of isolate 1a, SCII24 $4^{\mathrm{T}}, \mathrm{OgA} 9 \mathrm{a}^{\mathrm{T}}$, OiC8a and OiC8-6 were purified by low-melting agarose gel electrophoresis and sequenced following the dideoxy termination protocol of Anderson et al. (1992) using primers S3, S6, S8, S10, S12, S14, S15 and S17 (Ruimy et al., 1994). Electrophoresis was done in a Beckman Genomyx DNA sequencer with $6 \%$ polyacrylamide sequencing gels as described by Achouak et al. (1999). Amplificates of strains LMG 5140, CLM14 and CLM18 were purified using QIAquick PCR purification kit (Qiagen) and double strand sequencing was performed by custom service of TopLab using BigDye Terminator technology (Perkin Elmer Applied BioSystems).

16S rDNA from strain LAIII106, isolate 1a and OiC8a was additionally PCR-amplified using primers $63 \mathrm{f}$ and $1387 \mathrm{r}$
(Marchesi et al., 1998). DNA purification on QIAquick columns and double strand sequencing (BigDye Terminator technology; Perkin Elmer Applied BioSystems) was done by custom DNA sequencing service at Eurogentec.

EMBL/GenBank 16S rDNA sequences that were used for phylogenetic analyses are listed in Fig. 1. In addition to these, sequences D14501 of Agrobacterium rhizogenes IFO $13257^{\mathrm{T}}$ and X67223 of Agrobacterium tumefaciens LMG 196 were used.

The following bases of EMBL/GenBank sequences, for which results of secondary structure analysis (Gutell et al., 1994) indicated that they may not have been correctly determined, were replaced by $\mathrm{N}$ in our alignments (Escherichia coli numbering for EMBL/GenBank sequence A14565): 770, 771 (U88443); 860, 861 (U70978, U88440, U88441, U88442, U88443, U88444, X13695); 1042 (U88442); 1271 (D12794); 1343 (D12794); 1490 (D12794).

Alignments (CLUSTALW), similarity studies (FASTA) and phylogenetic analyses (CLUSTREE neighbour-joining, PUZZLE maximum-likelihood, PAUP and EDNAPARS maximum-parsimony) of $1292 \mathrm{nt}$ were performed at DKFZ Heidelberg on the GENIUSnet HUSAR computer (http://genome.dkfzheidelberg.de/biounit/) using Wisconsin Package Version 10.0 [Genetics Computer Group (GCG), Madison, Wisconsin]. Evolutionary distances were corrected for multiple substitutions using the implemented Kimura twoparameter model. Positions with gaps were excluded or treated as a fifth nucleotide state. Probability of nodes were calculated from 1000 bootstrap replications. Additional neighbour-joining, maximum-likelihood and parsimony trees were reconstructed using the same alignment and ARB software (http: \\www.mikro.biologie.tu-muenchen.de; Strunk \& Ludwig, 1996).

\section{Phenotypic characters}

(i) Colony morphology, growth, microscopy and aminopeptidase test. The immunotrapped strains were checked for colony morphology and development at 20, 30 and $37^{\circ} \mathrm{C}$ on NA, tryptone-yeast extract agar (TYA), Luria-Bertani agar (LBA) and 1/10 diluted LBA, 1/10 tryptic soy agar (1/10 TSA) (Atlas, 1995) and on MacConkey agar (bioMérieux 51036). Microbial growth was tested in nutrient bouillon (NB; Prolabo), LB and 1/10 TS (Difco) broth at the same temperatures.

Cell shape and motility were checked using a Zeiss Axioplan 2 epifluorescence microscope at $1000 \times$ magnification. The presence of flagella was visualized by SEM of $1 \%$ glutaraldehyde-fixed bacterial suspensions.

Aminopeptidase activity (Bactident; Merck) was tested according to the manufacturer's recommendations.

(ii) Substrate utilization, catalase and oxidase tests. BIOLOG-GN microtitre plates (Garland \& Mills, 1991) containing 95 different carbon sources were incubated with suspensions (in $0.85 \% \mathrm{KCl})$ of 61 randomly chosen representative strains (Fig. 2) from the different REP groups (see REP-PCR section). Strains were grown overnight at $30^{\circ} \mathrm{C}$ in $\mathrm{NB}$, washed twice in $0.85 \% \mathrm{KCl}$ and adjusted to OD 0.25 at $590 \mathrm{~nm}\left(5 \times 10^{8}\right.$ c.f.u. $\left.\mathrm{ml}^{-1}\right)$. After adding $150 \mu \mathrm{l}$ suspension to each microtitre plate well, plates were incubated for $24 \mathrm{~h}$ at $30{ }^{\circ} \mathrm{C}$ (two repetitions). Three substrate utilization levels (as a percentage of the water control) of the sole $\mathrm{C}$ sources were defined: positive $(+,>160 \%)$, borderline $( \pm$, 


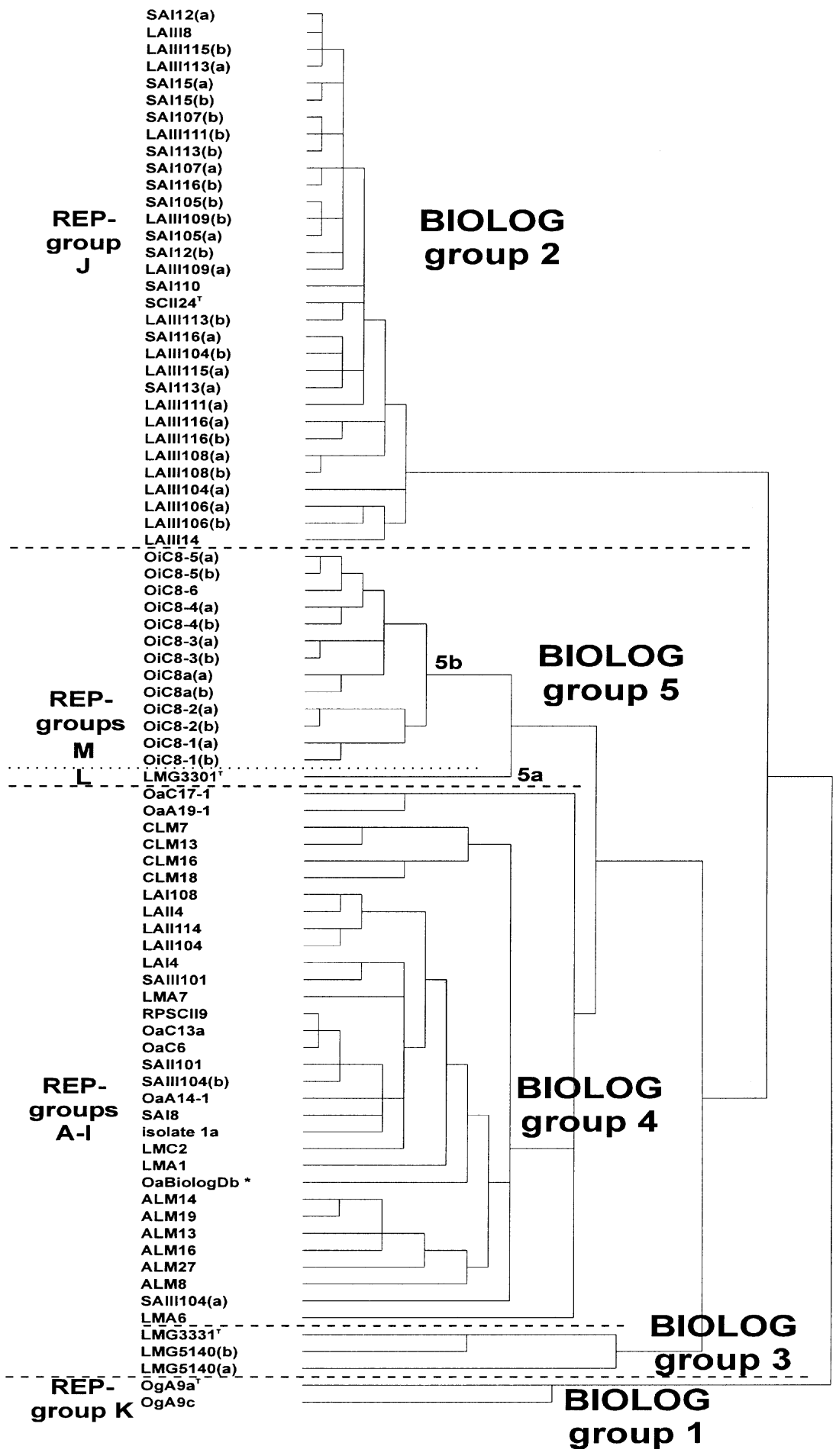

Fig. 2. Hierarchical cluster analysis of BIOLOG-GN substrate utilization profiles. Different profiles obtained for repetitions are marked by $(a, b)$. ${ }^{*}$ OaBiologDb, MICROLOG 2 release 3.50 database profile of $O$. anthropi.

$130-160 \%)$ and negative $(-,<130 \%)$. Substrate utilization profiles were compared to BIOLOG database profiles using MICROLOG 2 release 3.50 software and grouped on similarity by hierarchical cluster analysis using SPSS 6.1 for Windows. Carbon sources of diagnostic value for differentiation between species were identified.
Representative strains from the different BIOLOG clusters (BIOLOG group 1: strains OgA9a ${ }^{\mathrm{T}}$, OgA9c; BIOLOG group 2: strains SAI12, SCII24 ${ }^{\mathrm{T}}$, LAIII106; BIOLOG group 3: strains LMG $3331^{\mathrm{T}}$, LMG 5140; BIOLOG group 4: strains 1a, LAI4, SAII101; BIOLOG group 5: strains LMG $3301^{\mathrm{T}}$, OiC8-6) were additionally analysed for substrate 
conversion and oxidase activity using API 20NE and API $20 \mathrm{E}$ systems (bioMérieux). Tests and evaluations were performed as recommended by the manufacturer. Reactions were categorized as follows: positive, $100-60 \%$; borderline, $60-50 \%$; negative, $50-0 \%$.

Catalase activity of the strains was tested by addition of $3 \%$ $\mathrm{H}_{2} \mathrm{O}_{2}$ to colonies of bacteria on rigid black paper. Fast development of gas bubbles indicated a positive reaction.

(iii) Antibiotic tests. The above-mentioned representative strains from the different BIOLOG clusters were checked for sensitivity to the antibiotics chloramphenicol $(30 \mu \mathrm{g}$; bioMérieux 54072), polymyxin B (300 units; bioMérieux 54522), gentamicin (10 $\mu \mathrm{g}$; bioMérieux 54262) and colistin (10 $\mu \mathrm{g}$; bioMérieux 54102). Kirby-Bauer agar-diffusion tests (Mueller-Hinton 2 agar; bioMérieux 51075, at least six repetitions) and evaluation of sensitivity or resistance were performed according to the recommendations of the National Committee for Clinical Laboratory Standards, Bauer et al. (1966) and Velasco et al. (1998).

\section{RESULTS}

\section{Genotypic characters}

(i) REP-PCR. Table 2 shows the affiliation of immunotrapped, type and reference strains to REP groups and subgroups.

(ii) DNA base composition. Molar $\mathrm{G}+\mathrm{C}$ percentages of strains LAIII106, SAI12 and SCII24 from REP group $\mathbf{J}$ (Table 2) were $58 \cdot 8 \pm 0 \cdot 5,57 \cdot 4 \pm 0.4$ and $56 \cdot 2 \pm 0.5 \mathrm{~mol} \%$, respectively. $\mathrm{G}+\mathrm{C}$ contents of REP group $\mathrm{K}$ strains $\mathrm{OgA} 9 \mathrm{a}^{\mathrm{T}}$ and $\mathrm{OgA} 9 \mathrm{c}$ (Table 2) were $57 \cdot 8 \pm 0.3$ and $55 \cdot 3 \pm 0.5 \mathrm{~mol} \%$, respectively, and that of REP group $\bar{M}$ strain OiC8-6 (Table 2) was $59 \cdot 1 \pm 0 \cdot 2 \mathrm{~mol} \%$. These values correspond to the description of the genus Ochrobactrum (Holmes et al., 1988).

(iii) DNA-DNA hybridization and $\Delta T_{\mathrm{m}}$ determination. Results from the DNA-DNA hybridization experiments are presented in Table 3. The tested strains fell into four hybridization groups (Table 3): group 1, consisting of strains of REP groups A-I (including $O$. anthropi LMG $3331^{\mathrm{T}}$ and LMG 5140); group 2, consisting of strains of REP group $\mathbf{J}$; group 3, consisting of REP group K strain $\mathrm{OgA} 9 \mathrm{a}^{\mathrm{T}}$; and group 4 , consisting of strains of REP groups $\mathrm{L}$ and $\mathrm{M}$ (including $O$. intermedium $\mathrm{LMG} 3301^{\mathrm{T}}$ ).

(iv) Phylogenetic studies on $16 \mathrm{~S}$ rDNA and sequence accession numbers. The phylogenetic $16 \mathrm{~S}$ rDNA trees $(1292 \mathrm{nt})$ that were reconstructed by the different neighbour-joining, maximum-likelihood and maximum-parsimony methods showed identical topologies. CLUSTREE neighbour-joining trees presented the highest resolution of internal branching. The use of sequences X67223 (A. tumefaciens LMG $196)$ or D14501 (A. rhizogenes IFO $13257^{\mathrm{T}}$ ) as alternative or additive outgroups did not affect tree topology.

Fig. 1 shows a CLUSTREE neighbour-joining tree (Saitou \& Nei, 1987) using the Kimura two-parameter model
(Kimura, 1980) and 1000 bootstrap resamplings of $16 \mathrm{~S}$ rDNA sequences. Congruent topologies with PUZZLE maximum-likelihood (Strimmer \& Von Haeseler, 1996) and ARB (Strunk \& Ludwig, 1996) maximumparsimony trees are indicated. The sequences fell into five clades or lineages and the outgroups. Clade 1 comprised the sequences of $O$. intermedium $\mathrm{LMG}$ $3301^{\mathrm{T}}$ and LMG 3306 and of REP group $M$ strains OiC8a and OiC8-6. Clade 2 was composed of Brucella sequences. The sequence of REP group $\mathrm{K}$ strain $\mathrm{OgA} 9 \mathrm{a}^{\mathrm{T}}$ constituted genealogically independent cluster 3 (lineage 3 ) which branched deeper than clades 4 and 5 (see below). In clade 4 , the core $O$. anthropi sequences [O. anthropi sequences except U88444 of $O$. anthropi LMG 2320(t1)] were found. The partial sequences AJ242577 and AJ242576 of REP group B strain CLM14 and REP group F1 strain CLM18, respectively, were identical with core $O$. anthropi clade 4 sequences AJ242578 and AJ242580. Clade 5 consisted of sequences AJ242584 and AJ242579 of REP group J strains SCII24 ${ }^{\mathrm{T}}$ and LAIII106, respectively. Sequence U88444 of $O$. anthropi LMG 2320(t1) clustered most closely with clade 5 sequences and was separated from clade 5 by a node in CLUSTREE neighbour-joining analysis (Fig. 1). The short branch to clade 5 sequences was collapsed in our maximumlikelihood and parsimony trees, yielding polytomy (not shown). The node separating the cluster of clade 5 plus sequence U88444 from $O$. anthropi clade 4 and the collective of clades/clusters 1-3 was supported by bootstrap probability of $76 \%$ in the CLUSTREE neighbour-joining tree (Fig. 1), and of $65 \%$ and $72 \%$ in PUZZLE maximum-likelihood and ARB maximumparsimony analyses, respectively. The branch leading from this node to $O$. anthropi clade 4 was collapsed in maximum-likelihood and parsimony analyses, yielding polytomy (not shown).

The genus Ochrobactrum showed paraphyly: O. intermedium clade 1 was separated from the (core) Ochrobactrum clusters/clades 3-5 (containing the type species $O$. anthropi) by a node leading to Brucella clade 2 , and sequences of $O$. intermedium clade 1 were more homologous to those of the Brucella than to those of the (core) Ochrobactrum clade (Fig. 1).

\section{Phenotypic characters}

(i) Motility, cell shape, growth, colony morphology and aminopeptidase reaction. The studied bacteria were all short rods and highly motile. The rods belonging to REP groups A-I were $0.4-0.8 \times 0.3-0.4 \mu \mathrm{m}$, rods of REP group $\mathrm{K}$ were $0 \cdot 6-1 \cdot 2 \times 0 \cdot 4 \mu \mathrm{m}$, and rods of REP group J, L and M were 0.6-1.4 ×0.4-0.6 $\mu \mathrm{m}$. SEM showed that variable numbers of flagella can be present: two subpolar or several flagella with peritrichous insertion.

The tested strains grew slowly in/on diluted TS and LB, better in/on LB, TY and on MacConkey, and best in/on NB media/agar plates. The strains were able to 
M. Lebuhn and others

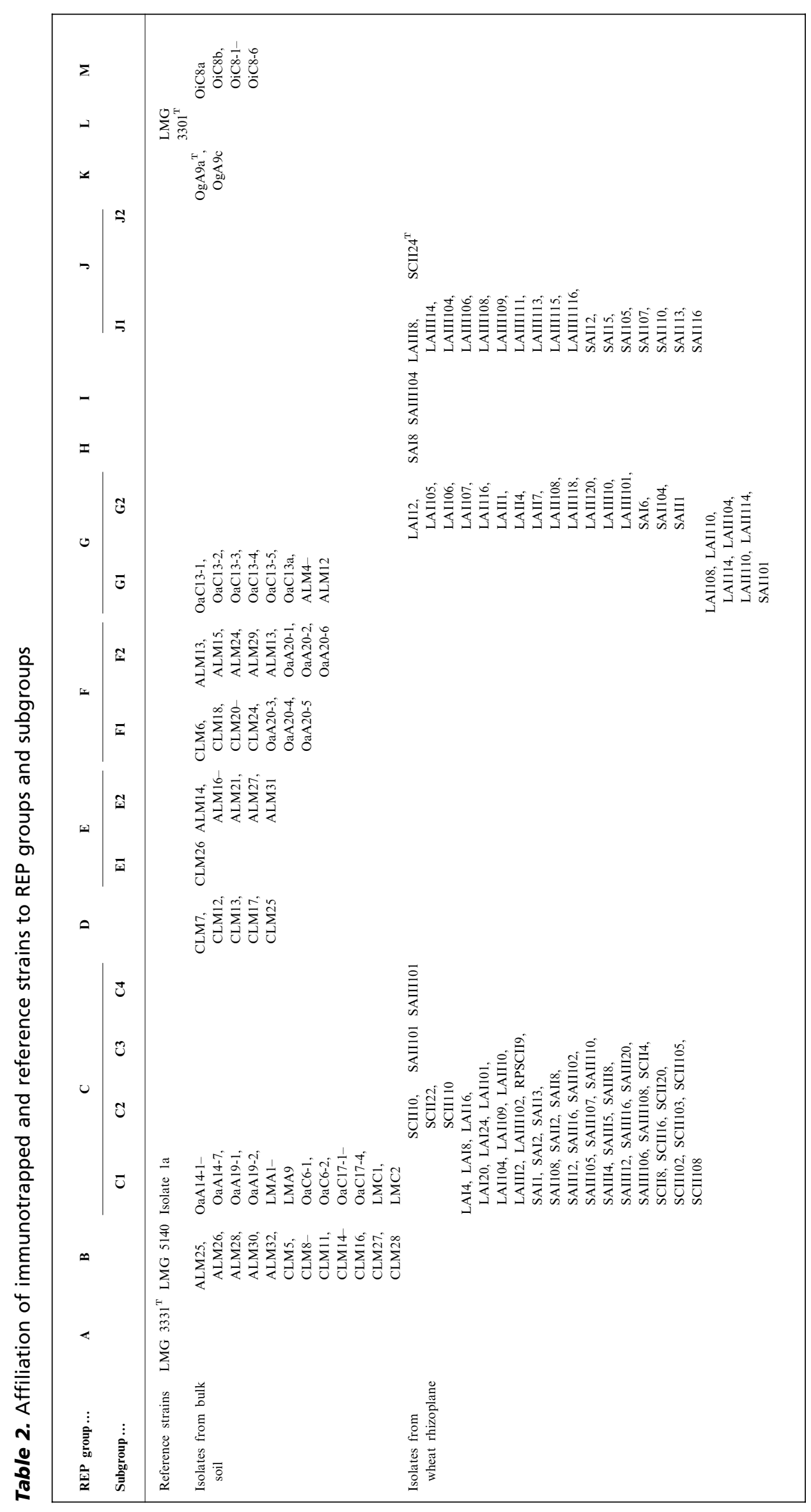


Table 3. DNA-DNA reassociation values and $\Delta T_{\mathrm{m}}$

\begin{tabular}{|c|c|c|c|c|c|c|}
\hline $\begin{array}{l}\text { DNA of strain } \\
\text { (REP group) }\end{array}$ & $\begin{array}{l}\text { Reassociation with } \\
\text { DNA from strain } \\
\text { LMG } 3331^{\mathrm{T}} \text { as } \\
\text { the probe }(\%)\end{array}$ & $\begin{array}{c}\Delta T_{\mathrm{m}} \text { to DNA } \\
\text { probe from strain } \\
\text { LMG } 3331^{\mathrm{T}}\left({ }^{\circ} \mathrm{C}\right)\end{array}$ & $\begin{array}{c}\text { Reassociation with } \\
\text { DNA from strain } \\
\text { LMG } 5140 \text { as the } \\
\text { probe }(\%)\end{array}$ & $\begin{array}{l}\text { Reassociation with } \\
\text { DNA from strain } \\
\text { OiC8-6 as the } \\
\text { probe }(\%)\end{array}$ & $\begin{array}{l}\text { Reassociation with } \\
\text { DNA from strain } \\
\text { SCII24 as the } \\
\text { probe }(\%)\end{array}$ & $\begin{array}{c}\text { Hybridization } \\
\text { group }\end{array}$ \\
\hline LMG $3331^{\mathrm{T}}(\mathrm{A})$ & 100 & 0 & & $45 \cdot 3 \pm 9 \cdot 2$ & $50 \cdot 4 \pm 4 \cdot 8$ & 1 \\
\hline LMG 5140 (B) & $91 \cdot 3 \pm 9 \cdot 2$ & & 100 & $50 \cdot 2 \pm 2 \cdot 3$ & $53 \cdot 8 \pm 8 \cdot 0$ & 1 \\
\hline CLM14 (B) & & & $97 \cdot 8 \pm 9 \cdot 7$ & $43 \cdot 9 \pm 4 \cdot 3$ & & 1 \\
\hline Isolate 1a (C1) & $69 \cdot 6 \pm 5 \cdot 2$ & & $84 \cdot 5 \pm 2 \cdot 2$ & $44 \cdot 2 \pm 5 \cdot 3$ & $57 \cdot 8 \pm 12 \cdot 4$ & 1 \\
\hline SAII16 (C1/2) & $74 \cdot 8 \pm 12 \cdot 8$ & & & & & 1 \\
\hline SAIII4 (C1/2) & $75 \cdot 5 \pm 11 \cdot 0$ & & & & & 1 \\
\hline SAIII12 (C1/2) & $78 \cdot 4 \pm 5 \cdot 2$ & & $73 \cdot 3 \pm 4 \cdot 1$ & $46 \cdot 0 \pm 5 \cdot 0$ & $52 \cdot 8 \pm 8 \cdot 8$ & 1 \\
\hline SCII20 $(\mathrm{C} 1 / 2)$ & $78 \cdot 4 \pm 15 \cdot 1$ & & $75 \cdot 7 \pm 14 \cdot 2$ & $40 \cdot 0 \pm 11 \cdot 8$ & $51 \cdot 3 \pm 9 \cdot 4$ & 1 \\
\hline SCII22 (C2) & & & $87 \cdot 7 \pm 11 \cdot 7$ & $48 \cdot 0 \pm 5 \cdot 3$ & & 1 \\
\hline CLM7 (D) & & & & & $54 \cdot 7 \pm 11 \cdot 2$ & 1 \\
\hline CLM12 (D) & $81 \cdot 0 \pm 10 \cdot 5$ & & $76 \cdot 4 \pm 5 \cdot 8$ & $54 \cdot 6 \pm 8 \cdot 1$ & & 1 \\
\hline ALM19 (E2) & $90 \cdot 1 \pm 21 \cdot 2$ & & $88 \cdot 5 \pm 8 \cdot 7$ & $42 \cdot 3 \pm 5 \cdot 8$ & $54 \cdot 5 \pm 8 \cdot 0$ & 1 \\
\hline CLM18 (F1) & $68 \cdot 7 \pm 8 \cdot 9$ & & & & & 1 \\
\hline CLM21 (F1) & & & $76 \cdot 5 \pm 16 \cdot 9$ & $41 \cdot 2 \pm 6 \cdot 0$ & & 1 \\
\hline ALM15 (F2) & $76 \cdot 8 \pm 5 \cdot 2$ & & $73 \cdot 4 \pm 5 \cdot 0$ & $44 \cdot 3 \pm 4 \cdot 0$ & $47 \cdot 4 \pm 5 \cdot 5$ & 1 \\
\hline ALM8 (G1) & $71 \cdot 1 \pm 12 \cdot 7$ & & $89 \cdot 6 \pm 15 \cdot 0$ & $46 \cdot 6 \pm 4 \cdot 7$ & $47 \cdot 7 \pm 3 \cdot 5$ & 1 \\
\hline LAI105 (G2) & $68 \cdot 6 \pm 13 \cdot 4$ & & & & & 1 \\
\hline LAII4 (G2) & & & $84 \cdot 4 \pm 7 \cdot 7$ & $49 \cdot 2 \pm 7 \cdot 0$ & & 1 \\
\hline LAII7 (G2) & $74 \cdot 5 \pm 22 \cdot 8$ & & $65 \cdot 9 \pm 8 \cdot 2$ & $42 \cdot 5 \pm 5 \cdot 6$ & $49 \cdot 0 \pm 2 \cdot 6$ & 1 \\
\hline SAI8 (H) & $87 \cdot 1 \pm 0 \cdot 7$ & & & $58 \cdot 1 \pm 0 \cdot 7$ & & 1 \\
\hline SAIII104 (I) & $71 \cdot 8 \pm 3 \cdot 1$ & $4 \cdot 4 \pm 0 \cdot 3$ & & $50 \cdot 6 \pm 5 \cdot 5$ & $63 \cdot 8 \pm 7 \cdot 3$ & 1 \\
\hline SCII $24^{\mathrm{T}}(\mathrm{J} 2)$ & $56 \cdot 1 \pm 0 \cdot 7$ & $8 \cdot 5 \pm 0 \cdot 2$ & & $46 \cdot 9 \pm 5 \cdot 0$ & 100 & 2 \\
\hline LAIII106 (J1) & $51 \cdot 0 \pm 0 \cdot 3$ & $8 \cdot 4 \pm 0 \cdot 3$ & & $40 \cdot 6 \pm 9 \cdot 4$ & $98 \cdot 4 \pm 9 \cdot 6$ & 2 \\
\hline SAI110 (J1) & $59 \cdot 8 \pm 0 \cdot 3$ & & $49 \cdot 3 \pm 8 \cdot 6$ & $42 \cdot 9 \pm 7 \cdot 0$ & $100 \cdot 3 \pm 10 \cdot 1$ & 2 \\
\hline $\mathrm{OgA} 9 \mathrm{a}^{\mathrm{T}}(\mathrm{K})$ & $17 \cdot 3 \pm 2 \cdot 1$ & & $20 \cdot 4 \pm 5 \cdot 1$ & $19 \cdot 2 \pm 1 \cdot 3$ & $17 \cdot 1 \pm 5 \cdot 6$ & 3 \\
\hline OiC8-6 (M) & $38 \cdot 6 \pm 5 \cdot 6$ & & & 100 & $40 \cdot 4 \pm 7 \cdot 7$ & 4 \\
\hline LMG $3301^{\mathrm{T}}(\mathrm{L})$ & $49 \cdot 5 \pm 0 \cdot 6$ & & & $88 \cdot 2 \pm 5 \cdot 5$ & $43 \cdot 8 \pm 8 \cdot 5$ & 4 \\
\hline $\mathrm{OiC8a}(\mathrm{M})$ & $48 \cdot 8 \pm 0 \cdot 5$ & & $39 \cdot 3 \pm 3 \cdot 5$ & & $33 \cdot 7 \pm 11 \cdot 6$ & 4 \\
\hline OiC8b (M) & $40 \cdot 7 \pm 6 \cdot 6$ & & & $95 \cdot 1 \pm 6 \cdot 9$ & $38 \cdot 3 \pm 11 \cdot 9$ & 4 \\
\hline OiC8-2 (M) & $42 \cdot 2 \pm 5 \cdot 9$ & & & $99 \cdot 1 \pm 5 \cdot 6$ & $44 \cdot 4 \pm 9 \cdot 7$ & 4 \\
\hline
\end{tabular}

grow at 4 and $40{ }^{\circ} \mathrm{C}$, and at $\mathrm{pH}$ values of 3-9. Optimum growth temperature was $30^{\circ} \mathrm{C}$ and the $\mathrm{pH}$ optimum was $\mathrm{pH} 6-7$.

After growth on NA for $24 \mathrm{~h}$, strains of REP groups A-G and I developed circular, low convex, smooth, shining, entire colonies of about $1 \mathrm{~mm}$ in diameter, with the exception that some rhizoplane isolates of REP groups C and G (strains LAI106, LAI108, LAI109, LAII1, LAII110, LAIII101, SAI1, SAI2, SAI6, SAII1, SAIII108, SCII105 and SCII108), as well as strain SAI8 (REP group H), soon became mucoid and opaque. Colonies of REP group J were mucoidopaque and quickly became highly confluent. Colonies of REP group $\mathrm{K}$ strains were circular, entire, low convex, smooth, milky-opaque and about $1 \mathrm{~mm}$ in diameter. Colonies of REP group $\mathrm{L}$ and $\mathrm{M}$ strains were mucoid-opaque and tended to confluency, with the exception of strain LMG $3301^{\mathrm{T}}$, which grew first as circular, low convex, smooth, shining, entire colonies that later became mucoid-opaque.
All tested strains were aminopeptidase-positive or effected borderline coloration, suggesting Gram-negative reaction. No pigment development was observed.

(ii) Substrate utilization, catalase and oxidase tests. All tested strains were catalase- and cytochrome oxidasepositive, suggesting aerobic metabolism. Fig. 2 shows a similarity dendrogram of BIOLOG-GN substrate utilization profiles of representative strains from the different REP groups (Table 2). Five distinct physiological BIOLOG clusters were obtained: BIOLOG group 1, consisting exclusively of REP group $\mathrm{K}$ strains; BIOLOG group 2, consisting only of REP group $\mathbf{J}$ strains; BIOLOG group 3, consisting of O. anthropi strains LMG $3331^{\mathrm{T}}$ and LMG 5140; BIOLOG group 4 (being most closely related to group 3), comprising REP group B-I strains (except strain LMG 5140) as well as the BIOLOG database profile of $O$. anthropi; and BIOLOG group 5, consisting of REP group $\mathrm{L} O$. intermedium strain $\mathrm{LMG} 3301^{\mathrm{T}}$ (constituting BIOLOG subgroup 5a) and the subcluster of 
Table 4. Diagnostic phenotypic characters for the differentiation between Ochrobactrum pheno- and genotypes

\begin{tabular}{|c|c|c|c|c|c|}
\hline \multirow{2}{*}{$\begin{array}{l}\text { Phenotyping } \\
\text { test }\end{array}$} & \multirow[t]{2}{*}{ Parameter } & \multicolumn{4}{|c|}{ REP group/BIOLOG group (Ochrobactrum species)* } \\
\hline & & $\mathrm{A}-\mathrm{I} / 3,4$ (O. anthropi) & $\begin{array}{c}\mathrm{J} / 2 \\
\text { (O. tritici) }\end{array}$ & $\begin{array}{c}\mathbf{K} / \mathbf{1} \\
\text { (O. grignonense) }\end{array}$ & $\begin{array}{c}\mathbf{L}, \mathbf{M} / \mathbf{5} \\
\text { (o. intermedium) }\end{array}$ \\
\hline \multirow[t]{14}{*}{ BIOLOG-GN } & $\gamma$-Hydroxybutyric acid & + & - & + & + \\
\hline & Sebacic acid & - to \pm & + & - to \pm & - \\
\hline & Adonitol & + & + & - & + \\
\hline & D-Glucosaminic acid & + & + & - & + \\
\hline & Malonic acid & - & - & + & - \\
\hline & D-Trehalose & $+\dagger$ & + & - & + \\
\hline & Quinic acid & $+\$$ & - & - & - \\
\hline & Xylitol & - to $\pm \S$ & - & \pm & $+\|$ \\
\hline & Cellobiose & + & - & - to \pm & + \\
\hline & Gentiobiose & + & - & - to \pm & + \\
\hline & Glycerol & \pm to +9 & - & + & - \\
\hline & DL- $\alpha$-Glycerol phosphate & \pm to $+\#$ & - to \pm & \pm to + & - \\
\hline & DL-Carnitine & $+* *$ & - to $\pm \dagger \dagger$ & - to \pm & + \\
\hline & Uridine & \pm to $+1+$ & - to \pm & + & - to \pm \\
\hline \multirow{4}{*}{ API $20 \mathrm{E}$} & Melibiose (acid production after $48 \mathrm{~h}$ ) & - & - & + & - \\
\hline & Arabinose (acid production after $48 \mathrm{~h}$ ) & - & - & \pm to + & - \\
\hline & Urease (after $24 \mathrm{~h}$ ) & + & + & - & - \\
\hline & Urease (after $48 \mathrm{~h}$ ) & + & + & - & \pm \\
\hline \multirow[t]{8}{*}{ API 20NE } & Mannose (assimilation after $24 \mathrm{~h}$ ) & - & - & + & - \\
\hline & Maltose (assimilation after $24 \mathrm{~h}$ ) & - to \pm & - to \pm & - & + \\
\hline & Maltose (assimilation after $48 \mathrm{~h}$ ) & + & + & - & + \\
\hline & Gluconate (assimilation after $48 \mathrm{~h}$ ) & - to \pm & + & - to \pm & - to \pm \\
\hline & Citrate (assimilation after $24 \mathrm{~h}$ ) & - & - to \pm & + & + \\
\hline & Citrate (assimilation after $48 \mathrm{~h}$ ) & - to \pm & \pm to + & + & + \\
\hline & Urease (after $24 \mathrm{~h}$ ) & + & + & - & - \\
\hline & Urease (after $48 \mathrm{~h}$ ) & + & + & - & - \\
\hline \multirow{3}{*}{$\begin{array}{l}\text { Sensitivity to } \\
\text { antibiotics }\end{array}$} & Polymyxin B & Susceptible & Susceptible & Resistant & Resistant \\
\hline & Colistin & Susceptible-intermediate & Susceptible & Resistant & Resistant \\
\hline & Chloramphenicol & Resistant & Intermediate & Susceptible-intermediate & Resistant \\
\hline $\begin{array}{l}\text { Colony } \\
\text { morphology }\end{array}$ & On nutrient agar (after $24 \mathrm{~h}$ ) & $\begin{array}{l}\text { Shiny/opaque, } \\
\text { isolated/mucoid }\end{array}$ & $\begin{array}{l}\text { Opaque, highly } \\
\text { confluent }\end{array}$ & Opaque, isolated & $\begin{array}{l}\text { Opaque, } \\
\text { mucoid/confluent\$̧ }\end{array}$ \\
\hline
\end{tabular}

* For values corresponding to symbols,+ \pm and - , see Methods, phenotypic characters.

$\dagger$ Isolate 1a, LMA1, ALM27: - to \pm .

† Strains LMG 3331 ${ }^{\mathrm{T}}$, LMG 5140: - to \pm .

$\S$ Strains CLM7, CLM13: +.

|| Strain LMG $3301^{\mathrm{T}}$ : - .

๑ Strains LAII114, LMA1, LMA6, OaA14-1, OaA19-1, OaC17-1, SAI8: - .

\# Strains LAI4, LAII104, LAII114, LMA1, LMA6, LMC2, OaA14-1, OaA19-1, OaC17-1, SAI8, SAII101, SAIII101: - .

** Strains CLM7, CLM13, LMG 3331 ${ }^{\mathrm{T}}$, LMG 5140: - to \pm .

$\dagger \dagger$ Strains LAIII111, LAIII115, SCII24 ${ }^{\mathrm{T}}:+$.

†t Strains LAI108, LMG 3331 ${ }^{\mathrm{T}}$ : - .

$\S \S$ Strain LMG $3301^{\mathrm{T}}$ : shiny, isolated/mucoid.

REP group $\mathrm{M}$ isolates (constituting BIOLOG subgroup 5b). MICROLOG 2 release 3.50 database profiles of Brucella abortus, Brucella canis, Brucella melitensis, Brucella neotomae, Brucella ovis and Brucella suis formed a separate branch that was again different from the cluster collective of BIOLOG group $1-5$ profiles (not shown).

MICROLOG database searching significantly identified BIOLOG group 3 and 4 strains (similarity $>75 \%$ ) as $O$. anthropi, except strains LMG 5140, LMA6 and OaA19-1, which were not identified significantly (similarities between 50 and $75 \%$ ) as $O$. anthropi. For BIOLOG group 5 strains, similarities to the $O$. anthropi database profile ranged between 71 and $86 \%$; for isolates of BIOLOG group 1, similarities were between
40 and $76 \%$ and for BIOLOG group 2, between 53 and $72 \%$.

All tested strains converted $(+)$ the following sole sources of carbon (BIOLOG-GN): Tween 40, Tween 80, L-arabinose, D-arabitol, i-erythritol, D-fructose, Lfucose, D-galactose, $\alpha$-D-glucose, m-inositol, maltose, D-mannose, psicose, L-rhamnose, turanose, monomethyl succinate, $\beta$-hydroxybutyric acid, $\alpha$-ketobutyric acid, $\alpha$-ketoglutaric acid, DL-lactic acid, succinic acid, bromosuccinic acid, D-alanine, L-alanine, L-alanyl-glycine, L-asparagine, L-aspartic acid, Lglutamic acid, glycyl-L-aspartic acid, glycyl-L-glutamic acid, L-histidine, hydroxy-L-proline, L-leucine, Lornithine, L-proline, L-serine, L-threonine, $\gamma$-aminobutyric acid and inosine. All representative strains 
from the five BIOLOG groups (including subgroups $5 \mathrm{a}$ and $5 \mathrm{~b}$; Fig. 2) gave positive $(+)$ reactions in the following API 20NE and API 20E tests: denitrification (gas production from $\mathrm{NO}_{3}^{-} / \mathrm{NO}_{2}^{-}$, reduction of $\mathrm{NO}_{3}^{-}$ to $\left.\mathrm{NO}_{2}^{-}\right)$, glucose assimilation $(48 \mathrm{~h})$, arabinose assimilation $(48 \mathrm{~h})$ and citrate utilization $(48 \mathrm{~h})$.

None of the tested strains utilized ( - ) L-phenylalanine or phenylethylamine as sole C source (BIOLOG-GN). All tested strains gave negative $(-)$ reactions in the following API 20NE and API 20E tests: indole production, glucose acidification (fermentation), arginine dihydrolase, gelatin hydrolysis (protease), $\beta$ galactosidase (PNPG), mannitol assimilation ( $24 \mathrm{~h}$ ), adipate assimilation, phenylacetate assimilation, $\beta$ galactosidase (ONPG), lysine decarboxylase, ornithine decarboxylase, citrate utilization $(24 \mathrm{~h}), \mathrm{H}_{2} \mathrm{~S}$ production, tryptophan deaminase, gelatinase, and acid production from glucose, mannitol, inositol, sorbitol, rhamnose, sucrose and amygdalin.

Physiological characters of diagnostic value for the identification of Ochrobactrum species (within BIOLOG groups 1-5) are listed in Table 4. Other individual physiological responses of strains are listed in Table 5.

In contrast to BIOLOG group 1-5 (Ochrobactrum spp.) strains, Brucella spp. did not utilize the following BIOLOG-GN substrates (data from MICROLOG 2 release 3.50 database): D-arabitol, m-inositol, psicose, L-rhamnose, bromosuccinic acid, L-alanine, L-alanylglycine, L-aspartic acid, glycyl-L-aspartic acid, Lhistidine, hydroxy-L-proline, L-leucine, L-threonine, $\gamma$-aminobutyric acid, sucrose, D-gluconic acid, Dglucuronic acid, $\mathrm{N}$-acetyl-D-glucosamine, cis-aconitic acid, citric acid, D-galactonic acid lactone, L-ornithine (Brucella canis, \pm ) and D-serine. Due to the high dissimilarity of Ochrobactrum spp. and Brucella spp. profiles, these genera were clearly separated in hierarchical cluster analysis (not shown).

(iii) Antibiotic tests. All tested representative strains from the five BIOLOG groups (including subgroups $5 \mathrm{a}$ and $5 \mathrm{~b}$; Fig. 2) were sensitive to gentamicin (strain LMG $3301^{\mathrm{T}}$, intermediate). Sensitivity reactions of the strains against polymyxin B, colistin and chloramphenicol were of diagnostic value for differentiation between BIOLOG groups 1-5. The differential responses are given in Table 4.

\section{DISCUSSION}

The aim of the present study was to assess the taxonomic affiliation of bacterial strains which were immunotrapped from soil and from the rhizoplane of wheat. For this purpose, a polyphasic approach (Vandamme et al., 1996) was used, assessing various geno- and phenotypic characters. Decision priority was given to the results of DNA-DNA hybridization because the phylogenetic approach using 16S rDNA homology has some limitations for species definition (Stackebrandt \& Goebel, 1994).
For the immunotrapping, $\mathrm{mAbs}$ raised against isolate 1 a were used. This strain has been characterized as $O$. anthropi by phenotypic features (Schloter et al., 1996). DNA-DNA reassociation values of $70 \%$ with DNA from $O$. anthropi LMG $3331^{\mathrm{T}}$ and $85 \%$ with DNA from $O$. anthropi LMG 5140 (Table 3), phenotypic affiliation of isolate 1a to BIOLOG group 4 (which clustered most closely with BIOLOG group 3 consisting of $O$. anthropi $\mathrm{LMG} 3331^{\mathrm{T}}$ and $O$. anthropi LMG 5140; Fig. 2), and 16S rDNA sequence identity with $O$. anthropi $\mathrm{LMG} 3331^{\mathrm{T}}$ and $O$. anthropi $\mathrm{LMG}$ 5140 (Fig. 1) prove that isolate 1a is $O$. anthropi.

The tested strain collection fell into 13 different REP groups (A-M; Table 2). Most strains of these 13 REP groups were tested by BIOLOG profiling (Fig. 2). Since only representative strains from the five BIOLOG groups were characterized by additional phenotyping tests (API 20E, API 20NE and sensitivity to antibiotics; Table 4), further phenotyping studies should be performed with a larger set of strains to confirm the differentiating value of the respective diagnostic characters presented in Table 4. Selecting representatives from the different REP groups for DNA-DNA reassociation and 16S rDNA homology studies (Table 3, Fig. 1) is justified because REP profiling resolves below the species level (Louws et al., 1996; Vandamme et al., 1996), which is currently defined by values for reassociation of heterologous DNA of $\geqslant 70 \%$ and $\Delta T_{\mathrm{m}}$ values of less than $5^{\circ} \mathrm{C}$ (Stackebrandt \& Goebel, 1994). Taxonomy using 16S rDNA homology provides less resolution. There is no report that two strains sharing the same REP profile belong to different species.

BIOLOG group 3 profiles (O. anthropi LMG $3331^{\mathrm{T}}$ of REP group A and $O$. anthropi LMG 5140 of REP group B) were most similar to the cluster of BIOLOG group 4 profiles (REP group B-I strains) (Fig. 2). Since no difference between the REP profiles of $O$. anthropi LMG 5140 and REP group B strains was found (Table 2), BIOLOG group 4 strains constitute a phenotype which is different from BIOLOG group 3 strains. However, these two phenotypes should be held as one species because they were almost identical in their genotypic character (see below). Representatives of BIOLOG group 3 and 4 (REP group A-I) strains were clearly distinguishable by several diagnostic characters from BIOLOG group 1, 2 and 5 (REP group $\mathrm{J}-\mathrm{M}$ ) strains (Table 4). Representatives from REP group A-I (BIOLOG groups 3 and 4) strains formed the coherent DNA-DNA reassociation group 1 containing $O$. anthropi type and reference strains (Table 3 ). It is therefore concluded, and phylogenetic analyses did not contradict this (see below), that REP group A-I strains are $O$. anthropi.

In our phylogenetic analysis of $16 \mathrm{~S}$ rDNA sequences using CLUSTREE neighbour-joining, monophyly of clade 4 , consisting of core $O$. anthropi sequences [excluding sequence U88444 of $O$. anthropi LMG $2320(\mathrm{t} 1)$ ], was weakly supported (probability of $61 \%$ 
Table 5. Physiological characters of Ochrobactrum sp. strains

\begin{tabular}{|c|c|c|c|}
\hline $\begin{array}{l}\text { Physiological } \\
\text { character }\end{array}$ & $\begin{array}{c}\text { Strains giving } \\
\text { positive }(+) \text { results* }\end{array}$ & $\begin{array}{c}\text { Strains giving } \\
\text { borderline }( \pm) \text { results* }\end{array}$ & $\begin{array}{c}\text { Strains giving } \\
\text { negative }(-) \text { results* }\end{array}$ \\
\hline$\alpha$-Cyclodextrin $\dagger$ & $92 \%$ & LMA6, CLM16, CLM7, CLM13, OgA9c & \\
\hline Dextrin $\dagger$ & & $\mathrm{OgA} 9 \mathrm{a}^{\mathrm{T}}$ & \\
\hline Glycogen $\dagger$ & $75 \%$ & $\begin{array}{l}\text { ALM13, isolate 1a, LAI4, LAI108, } \\
\text { LAII104, LAII114, LMA6, OaA14-1, } \\
\text { OaC17-1, OgA9c, SAIII101 }\end{array}$ & $\begin{array}{l}\text { ALM14, ALM19, } \\
\text { ALM27, OaA19-1 }\end{array}$ \\
\hline$N$-Acetyl-D-galactosamine $\dagger$ & $84 \%$ & $\begin{array}{l}\text { LAIII111, LAIII116(a), LMG 5140, } \\
\text { OiC8a, OiC8-2, OiC8-3, OiC8-4(a), } \\
\text { OiC8-5, OiC8-6 }\end{array}$ & $\begin{array}{l}\text { ALM13, LAIII116(b), } \\
\text { OiC8-4(b) }\end{array}$ \\
\hline$N$-Acetyl-D-glucosamine $\dagger$ & $98 \%$ & & LMA1 \\
\hline$\alpha$-Lactose $\dagger$ & & OaA19-1, LMA7 & $97 \%$ \\
\hline$\alpha$-D-Lactose lactulose $\dagger$ & & Isolate $1 \mathrm{a}$ & $98 \%$ \\
\hline D-Mannitol† & $87 \%$ & $\begin{array}{l}\text { LAIII14, LAIII104, LAIII106(b), LAIII108, } \\
\text { LAIII109, LAIII111(b), LMG 3301 }{ }^{\mathrm{T}} \text {, } \\
\text { LMG 5140(b), SAI105, SAI107, SAI110 }\end{array}$ & \\
\hline D-Melibiose $\dagger$ & ALM8 & $\begin{array}{l}\text { ALM13, CLM7, CLM13, CLM16, } \\
\text { LMA1, LMA7, LMG 3301 } \\
\text { OaA14-1, OgA9a }\end{array}$ & $84 \%$ \\
\hline Methyl $\beta$-D-glucoside $\dagger$ & $\begin{array}{l}\text { ALM8, ALM14, } \\
\text { ALM16, ALM19 }\end{array}$ & $\begin{array}{l}\text { ALM13, CLM13, LMA6, LMA7, } \\
\text { LMG 3301 }{ }^{\mathrm{T}}, \mathrm{LMG} 3331^{\mathrm{T}}, \text { OaA14-1, } \\
\text { OgA9a }{ }^{\mathrm{T}}, \text { OgA9c, }\end{array}$ & $79 \%$ \\
\hline D-Raffinose $\dagger$ & & ALM8 & $98 \%$ \\
\hline D-Sorbitol† & $98 \%$ & LAIII106(b) & $\mathrm{OgA} 9 \mathrm{c}$ \\
\hline Sucrose $\dagger$ & $98 \%$ & $\mathrm{OgA} 9 \mathrm{a}^{\mathrm{T}}$ & \\
\hline Methyl pyruvate $\dagger$ & $95 \%$ & LMG $3301^{\mathrm{T}}, \mathrm{OiC} 8-5$ & LMA6 \\
\hline Acetic acid $\dagger$ & $95 \%$ & OgA9a ${ }^{T}$ & LAIII108, LMA6 \\
\hline$c i s$-Aconitic acid $\dagger$ & $95 \%$ & LMG $3331^{\mathrm{T}}$, SAI113, SAI116(b) & LMG 5140 \\
\hline Citric acid $\dagger$ & & LMG 5140(b) & LMG $3331^{\mathrm{T}}$ \\
\hline Formic acid $\dagger$ & $89 \%$ & $\begin{array}{l}\text { LMG 5140, SAI107(a), SAI110, } \\
\text { SAI116(b), OiC8-5, OiC8-6 }\end{array}$ & OiC8a, OiC8-3, OiC8-4 \\
\hline D-Galactonic acid lactone $\dagger$ & $97 \%$ & OiC8-2 & LMG 5140(b), OgA9c \\
\hline D-Galacturonic acid $\dagger$ & $67 \%$ & $\begin{array}{l}\text { ALM13, ALM14, ALM16, CLM7, } \\
\text { LAIII104(b), LMC2, LMG 3301 } \\
\text { LMG 5140(a), OaC17-1, OiC8-3, } \\
\text { OiC8-4(a), OiC8-5(b), OiC8-6, } \\
\text { SAIII104 }\end{array}$ & $\begin{array}{l}\text { ALM19, ALM27, LAI4, } \\
\text { LAIII104(a), LMA7, } \\
\text { LMG 3331 }{ }^{\mathrm{T}}, \text { LMG 5140(b), } \\
\text { OaA19-1, OiC8-4(b), } \\
\text { SAIII101 }\end{array}$ \\
\hline $\mathrm{D}-$ Gluconic acid $\dagger$ & $95 \%$ & LMG 5140(a), OiC8-4, OiC8-5, OiC8-6 & \\
\hline D-Glucuronic acid $\dagger$ & $97 \%$ & LMG $3301^{\mathrm{T}}, \mathrm{LMG} 3331^{\mathrm{T}}$ & \\
\hline$\alpha$-Hydroxybutyric acid $\dagger$ & $98 \%$ & OaA19-1 & LMG 5140(a) \\
\hline$p$-Hydroxyphenylacetic acid $\dagger$ & & $\begin{array}{l}\text { CLM7, CLM13, LAIII113(b), LMA7, } \\
\text { LMG 3301 }{ }^{\mathrm{T}}, \text { LMG 3331 }{ }^{\mathrm{T}} \text {, OgA9c, } \\
\text { OiC8-1, SAI12(b), SAI105(a), SAI110, } \\
\text { SAI113(a), SAIII104(a), SCII24 }{ }^{\mathrm{T}}\end{array}$ & $85 \%$ \\
\hline Itaconic acid $\dagger$ & LMC2 & CLM7, CLM16, OgA9c & $93 \%$ \\
\hline$\alpha$-Ketovaleric acid $\dagger$ & $77 \%$ & $\begin{array}{l}\text { LAI4, LAI108, LAII4, LAII104, } \\
\text { LAII114, LMC2, LMG 3301 } \\
\text { LMG 5140(a), OaC17-1, OiC8a(a), } \\
\text { OiC8-4, OiC8-5, OiC8-6, SAI8, }\end{array}$ & OaA19-1, OiC8-2 \\
\hline Propionic acid $\dagger$ & $90 \%$ & Isolate $1 \mathrm{a}, \mathrm{OgA} 9 \mathrm{a}^{\mathrm{T}}$ & $\begin{array}{l}\text { LAIII14, LMA6, } \\
\text { OaA19-1, OaC17-1 }\end{array}$ \\
\hline $\mathrm{D}-$ Saccharic acid $\dagger$ & & LMA7, OgA9 ${ }^{T}$ & $97 \%$ \\
\hline Alaninamide $\dagger$ & $92 \%$ & OaA19-1 & $\begin{array}{l}\text { LAI108, LAII4, } \\
\text { LAII104, LAII114 }\end{array}$ \\
\hline
\end{tabular}


Table 5 (cont.)

\begin{tabular}{|c|c|c|c|}
\hline $\begin{array}{l}\text { Physiological } \\
\text { character }\end{array}$ & $\begin{array}{c}\text { Strains giving } \\
\text { positive }(+) \text { results* }\end{array}$ & $\begin{array}{c}\text { Strains giving } \\
\text { borderline }( \pm) \text { results* }\end{array}$ & $\begin{array}{c}\text { Strains giving } \\
\text { negative }(-) \text { results* }\end{array}$ \\
\hline L-Pyroglutamic acid $\dagger$ & CLM18 & ALM16, CLM7, CLM13 & $93 \%$ \\
\hline $\mathrm{D}-$ Serine $\uparrow$ & $97 \%$ & LMG $3331^{\mathrm{T}}$ & LMG 5140 \\
\hline Urocanic acid $\dagger$ & $98 \%$ & SAI15 & \\
\hline Thymidine $\dagger$ & & $\begin{array}{l}\text { CLM7, CLM16, CLM13, CLM18, } \\
\text { LMG 5140(a), OgA9c }\end{array}$ & $92 \%$ \\
\hline Putrescine $\dagger$ & & $\begin{array}{l}\text { CLM7, isolate 1a, } \\
\text { LMG 5140(a), OgA9c }\end{array}$ & $95 \%$ \\
\hline 2-Aminoethanol $\dagger$ & & CLM16, LAII4, LMG 5140(a) & $97 \%$ \\
\hline 2,3-Butanediol $\dagger$ & & $\begin{array}{l}\text { ALM16, CLM7, LAIII104(b), } \\
\text { LAIII106(a), LAIII113(b), LAIII115(a), } \\
\text { LAIII116, LMG 5140, OgA9c, } \\
\text { SAI8, SAI15, SAI113(a), } \\
\text { SAI116(a), SAIII104(a) }\end{array}$ & $89 \%$ \\
\hline Glucose 1-phosphate† & & $\begin{array}{l}\text { LAIII104(b), LAIII108(b), LAIII111(a), } \\
\text { LAIII115(a), LMG 5140(a), SAI110, } \\
\text { SAI113(a), SAI116(a), SAIII104 }\end{array}$ & $97 \%$ \\
\hline Glucose 6-phosphate $\dagger$ & CLM13, CLM16 & $\begin{array}{l}\text { ALM8, ALM19, CLM7, CLM18, } \\
\text { LAI108, LAII4, LAIII104(b), } \\
\text { LAIII106(a), LAII108, LAIII11, } \\
\text { LAII1113(b), LAIII115, LMA7, } \\
\text { LMG 3331 }{ }^{\mathrm{T}} \text {, LMG 5140, OaC13a, } \\
\text { OgA9c, OiC8-5(a), OiC8-1(b), } \\
\text { OiC8-2, OiC8-3(b), RPSCII9, } \\
\text { SAI15, SAI107(b), SAI110, } \\
\text { SAI113, SAI116(a), SAIII101, } \\
\text { SAIII104, SCII24 }\end{array}$ & $61 \%$ \\
\hline Aesculin hydrolysis $(24 \mathrm{~h}) \$$ & & $\mathrm{SCII} 24^{\mathrm{T}}$ & $92 \%$ \\
\hline Aesculin hydrolysis $(48 \mathrm{~h}) \%$ & $\begin{array}{l}\text { LMG } 3301^{\mathrm{T}}, \text { SAI12, } \\
\text { SCII } 24^{\mathrm{T}}\end{array}$ & & $75 \%$ \\
\hline Glucose assimilation $(24 \mathrm{~h}) \ddagger$ & $\begin{array}{l}\text { LMG } 3331^{\mathrm{T}} \\
\text { OgA9 } \mathrm{a}^{\mathrm{T}}, \text { OgA9c }\end{array}$ & Isolate $1 \mathrm{a}, \mathrm{SAI} 12, \mathrm{SCII} 24^{\mathrm{T}}$ & $50 \%$ \\
\hline Arabinose assimilation $(24 \mathrm{~h}) t$ & & $67 \%$ & $\begin{array}{l}\text { Isolate 1a, LAIII106, } \\
\text { LMG 5140, SAII101 }\end{array}$ \\
\hline Mannose assimilation $(48 \mathrm{~h}) \dagger$ & $50 \%$ & LAIII106, LMG $3331^{\mathrm{T}}$, SCII24 ${ }^{\mathrm{T}}$ & LAI4, LMG 5140, SAII101 \\
\hline Mannitol assimilation $(48 \mathrm{~h})$ & SAI12 & Isolate $1 \mathrm{a}, \mathrm{LMG} 3301^{\mathrm{T}}, \mathrm{SCII} 24^{\mathrm{T}}$ & $67 \%$ \\
\hline $\begin{array}{l}N \text {-Acetylglucosamine } \\
\text { assimilation }(24 \mathrm{~h})\end{array}$ & $\begin{array}{l}\text { LMG } 3301^{\mathrm{T}} \\
\text { OgA9 } 9 \mathrm{a}^{\mathrm{T}}, \text { OgA9c }\end{array}$ & LAIII106, SAI12, SCII24 ${ }^{\mathrm{T}}$ & $42 \%$ \\
\hline $\begin{array}{l}N \text {-Acetylglucosamine } \\
\text { assimilation }(48 \mathrm{~h}) \ddagger\end{array}$ & $83 \%$ & LAI4, SAII101 & \\
\hline Gluconate assimilation $(24 \mathrm{~h})$ \% & & LAIII106, OgA9a ${ }^{\mathrm{T}}, \mathrm{SCII} 24^{\mathrm{T}}$ & $75 \%$ \\
\hline Caprate assimilation $(24 \mathrm{~h}) ‡$ & & SAI12, SCII $24^{\mathrm{T}}$ & $83 \%$ \\
\hline Caprate assimilation $(48 \mathrm{~h}) \ddagger$ & $58 \%$ & LAI4, LMG 5140, SAII101, OgA9a & LMG $3331^{\mathrm{T}}$ \\
\hline Malate assimilation $\$$ & $92 \%$ & & SAI12 \\
\hline Acetoin production & & LMG $3331^{\mathrm{T}}, \mathrm{OgA} 9 \mathrm{a}^{\mathrm{T}}, \mathrm{Og} A 9 \mathrm{c}$ & $75 \%$ \\
\hline
\end{tabular}

* (a) and (b) denote different responses of a strain in repeated experiments. For values corresponding to symbols,+ \pm and $-($ see Methods, phenotypic characters section).

$\dagger$ Utilization, using BIOLOG-GN system.

† Using API 20NE or API 20E systems.

for the respective node; Fig. 1) and separated from clade 5 (sequences AJ242584 and 242579 of REP group J strains SCII $24^{\mathrm{T}}$ and LAIII106), which represents a novel Ochrobactrum species (Ochrobactrum tritici sp. nov., see below). The branch of clade 4 was collapsed to the subterminal node in maximumlikelihood and maximum-parsimony trees, yielding polytomy. This may be due to the very high $16 \mathrm{~S}$ rDNA similarity of $O$. anthropi and $O$. tritici sp. nov. strains of about $99 \%$. Stackebrandt \& Goebel (1994) showed 
that the phylogenetic 16S rDNA approach possesses almost no resolution for species delineation at similarity values above $97.5 \%$, as compared to DNADNA hybridization approaches. Accordingly, our results show that phylogeny of $16 \mathrm{~S}$ rDNA is not suitable for delineation of these two species (see also below).

O. anthropi strains LMG 2320(t1), LMG 5140 and LMG 2134 are considered to be identical in the BCCM/LMG bacteria collection. However, sequence U88444 of $O$. anthropi LMG 2320(t1) clustered most closely with clade 5 sequences (REP group J strains, $O$. tritici sp. nov., see below), whereas sequence AJ 242580 of $O$. anthropi LMG 5140 clustered with clade 4 core $O$. anthropi sequences in our reconstructed $16 \mathrm{~S}$ rDNA trees (e.g. Fig. 1). Only four consecutive base pairs in the hypervariable helix 10 differentiated clade 5 from clade 4 sequences (not shown). O. anthropi LMG $2320(\mathrm{t} 1)$ (and $O$. intermedium strains) shared the typical sequence of clade 5 strains (GAAA), but $O$. anthropi LMG 5140 had the typical sequence of $O$. anthropi clade 4 (TTCG). Jumas-Bilak et al. (1998) showed that $O$. anthropi and $O$. intermedium have two chromosomes and two rrn genes. Assuming that this is also the case for clade 5 strains (O. tritici sp. nov.), an explanation for the observed heterogeneity may be that $16 \mathrm{~S}$ rDNA operons are different in the respective regions, and that either one or the other 16S rDNA was preferentially amplified during PCR. Genetic crossing-over in ribosomal sequences (Sneath, 1993) also cannot be excluded. Again, this suggests that phylogeny of $16 \mathrm{~S}$ rDNA is not suited to delineate clade 4 (O. anthropi) and clade 5 strains (O. tritici sp. nov.). However, the taxonomic position of $O$. anthropi $\mathrm{LMG}$ $2320(\mathrm{t} 1)$ is hence uncertain and should be re-examined.

REP group L (O. intermedium LMG $3301^{\mathrm{T}}$ ) and REP group $\mathrm{M}$ strains formed the coherent phenotypic cluster of BIOLOG group 5 (Table 2, Fig. 2). Several phenotypic parameters were found which differentiated representatives of this group from BIOLOG group 1-4 strains (Table 4). Representatives from BIOLOG group 5 constituted DNA-DNA reassociation group 4 containing $O$. intermedium type strain LMG $3301^{\mathrm{T}}$ (Table 3), and $16 \mathrm{~S}$ rDNAs of strains OiC8a and OiC8-6 were most homologous to those of $O$. intermedium strains (Fig. 1). The $\mathrm{G}+\mathrm{C}$ content of $59 \cdot 1 \mathrm{~mol} \%$ for strain OiC $8-6$ corresponds to the value given for the genus Ochrobactrum (Holmes et al., 1988). It is concluded that REP group M strains are $O$. intermedium.

In our phylogenetic trees of $16 \mathrm{~S}$ rDNA sequences (e.g. Fig. 1), clade 1 of $O$. intermedium sequences was found to be more closely related to clade 2 of Brucella sequences than to clade 4 sequences of the type species Ochrobactrum anthropi. Velasco et al. (1998) also presented this paraphyly of Ochrobactrum. Paraphyly is not rare in the $\alpha$-2-subclass of the Proteobacteria and is the source of taxonomic debates (Yanagi \& Yamasato, 1993; Moreno, 1997). However, results from rRNA-DNA hybridization (De Ley et al., 1987) suggested a position for $O$. intermedium between and equally distant from Brucella spp. and $O$. anthropi. DNA-DNA hybridization studies indicated an even closer relationship of $O$. intermedium to $O$. anthropi than to Brucella spp. (Holmes et al., 1988). The genera Brucella and Ochrobactrum were clearly separated in the dendrogram on various phenotypic characters presented by Holmes et al. (1988) as well as in our cluster analysis of BIOLOG profiles (not shown). Since the phylogenetic 16S rRNA approach possesses low resolution at the terminal branches as compared to DNA-DNA hybridization when $16 \mathrm{~S}$ rDNA similarity values are high (Stackebrandt \& Goebel, 1994), and 16S rDNA similarity between the genera Ochrobactrum and Brucella show even values of over $96 \%$ (Fig. 1; Velasco et al., 1998), it seems to be reasonable to base polyphasic taxonomy of the Ochrobactrum-Brucella group predominantly on the results of DNA-DNA hybridization and phenotyping. Concerning the paraphyly of Ochrobactrum, a taxonomic revision of the genus is strongly recommended. A possible solution, yielding monophyletic lineages which correspond to the results from genotyping, would be to give $O$. intermedium the status of a new genus. This will be a matter for a subsequent paper.

Very few phenotypic features differentiate $O$. intermedium from O. anthropi (Holmes et al., 1988; Velasco et al., 1998). Using API 20E and API 20NE systems, strong assimilation of maltose (after $24 \mathrm{~h}$ ) and citrate, as well as no or very low urease activity of $O$. intermedium, were found to be additional diagnostic characters to distinguish these two species (Table 4). However, Velasco et al. (1998) reported urease activity for $O$. intermedium and citrate utilization was reported by Velasco et al. (1998) for $O$. anthropi and by Holmes et al. (1988) for O. anthropi CIP $14970^{\mathrm{T}}$ (= LMG $3331^{\mathrm{T}}$ ). In contrast to our results, Velasco et al. (1998) report no $\mathrm{H}_{2} \mathrm{~S}$ production for $O$. anthropi and $O$. intermedium. In agreement with Velasco et al. (1998), no arabinose utilization (acid production) was obtained for $O$. anthropi and $O$. intermedium, whereas Holmes et al. (1988) reported positive D- and Larabinose utilization for all tested Ochrobactrum strains. D-Mannose assimilation was negative and gluconate assimilation was very low for $O$. anthropi and $O$. intermedium in our experiments, but D-mannose and gluconate utilization were positive for both species in the tests of Holmes et al. (1988). These differences may be explained in part by the use of different test systems. Holmes et al. (1988) used API 50AA, API $50 \mathrm{AO}$ and API 50CH galleries, and Velasco et al. (1998) API 20NE, GNI and BBL Crystal E/NF systems. Results for substrate assimilation (increase in turbidity) may also be different from respective results for substrate utilization (acidification) and metabolic differences may be due to different culture conditions. A coherent study with a larger set of strains may resolve these contradictions.

REP group $\mathrm{K}$ strains $\mathrm{OgA} 9 \mathrm{a}^{\mathrm{T}}$ and $\mathrm{OgA} 9 \mathrm{c}$ constituted BIOLOG group 1 (Table 2, Fig. 2). Their profiles were 
most closely related to BIOLOG group 3 and 4 profiles of $O$. anthropi (Fig. 2), and quite different from BIOLOG profiles of Brucella spp. strains (not shown). BIOLOG group 1 strains were clearly separated by several diagnostic phenotypic characters from BIOLOG group 2-5 strains of $O$. tritici sp. nov. (see below), $O$. anthropi, and $O$. intermedium (Table 4). DNA-DNA reassociation values for strain $\mathrm{OgA} 9 \mathrm{a}^{\mathrm{T}}$ with $O$. anthropi, $O$. intermedium and hybridization group 2 (REP group $\mathbf{J}, O$. tritici sp. nov., see below) references were as low as $20 \%$ (Table 3 ). In each of our phylogenetic 16S rDNA trees (e.g. Fig. 1), strain OgA9 $\mathrm{a}^{\mathrm{T}}$ represented a genealogically independent branch exhibiting high bootstrap probabilities (74$98 \%$ ). A reason for the variability of bootstrap support between the different applied methods might be that $16 \mathrm{~S}$ rDNA similarity to $O$. anthropi and $O$. tritici sp. nov. (REP group J) sequences, the closest relatives, was as high as about $98 \%$, a value that is at the limit of the delineation capacity of phylogenetic 16S rDNA approaches (Stackebrandt \& Goebel, 1994). According to our congruent results from genotypic, phenotypic and phylogenetic analyses, REP group K strains must be given the status of a novel species within the genus Ochrobactrum. REP group K strains fulfilled the criteria given for the genus Ochrobactrum by Holmes et al. (1988). Ochrobactrum grignonense sp. nov. is proposed for REP group K strains $\mathrm{OgA} 9 \mathrm{a}^{\mathrm{T}}$ and $\mathrm{OgA9c}$ because both strains were isolated from soil of the Grignon Experimental Station. Strain $\mathrm{OgA} 9 \mathrm{a}^{\mathrm{T}}$ is the type strain of Ochrobactrum grignonense sp. nov. The description of $O$. grignonense is given below.

EMBL sequences D63836 (Ochrobactrum sp.) and $\mathrm{U} 71004$ (O. anthropi) clustered most closely with the sequence of $O$. grignonense $\mathrm{OgA9} \mathrm{a}^{\mathrm{T}}$ (not shown). It is therefore suggested that the taxonomic position of the respective strains is re-examined.

REP group $\mathbf{J}$ strains constituted the coherent cluster of BIOLOG group 2 (Table 2, Fig. 2). Their BIOLOG profiles were most closely related to those of $O$. anthropi (Fig. 2) and quite different from those of Brucella spp. (not shown). Several diagnostic phenotypic characters differentiating BIOLOG group 2 from the other BIOLOG groups were found (Table 4). BIOLOG group 2 representatives constituted the coherent DNA-DNA reassociation group 2 (Table 3 ). This group showed DNA-DNA reassociation values of less than $60 \%$ with both $O$. anthropi probes and $\Delta T_{\mathrm{m}}$ values with $O$. anthropi LMG $3331^{\mathrm{T}}$ DNA were higher than $8^{\circ} \mathrm{C}$. Reassociation values with $O$. intermedium and $O$. grignonense sp. nov. DNA were even less (50 and $20 \%$, respectively; Table 3 ).

In our different phylogenetic $16 \mathrm{~S}$ rDNA trees (e.g. Fig. 1), sequence U88444 of $O$. anthropi LMG 2320(t1) was most closely related to clade 5 (REP group J sequences, see above). Since the taxonomic position of $O$. anthrop $i$ LMG 2320(t1) is uncertain (see above), sequence U88444 was not included in clade 5. Bootstrap support for the delineation of REP group $\mathrm{J}$ and $O$. anthropi sequences was low. The phylogenetic approach using $16 \mathrm{~S}$ rDNA similarity was hence not able to differentiate clearly between REP group $\mathrm{J}$ strains and $O$. anthropi. However, our results on DNA-DNA reassociation and the presence of diagnostic phenotypic characters (see above) suggest that REP group J strains represent a species that is different from $O$. anthropi. This position is reinforced by a biological particularity of REP group $\mathbf{J}$ strains: their activity apparently depends strongly on the presence of plant roots because they were immunotrapped exclusively from the rhizoplane and not from soil (Tables 1 and 3). This suggests adaptation of REP group $J$ strains to the specific rhizoplane habitat. This preference was not observed for other Ochrobactrum species.

The differences at the geno- and phenotype level and the ecological particularity suggest that REP group $J$ strains must be given the status of a new species. REP group J strains correspond to the description of the genus Ochrobactrum (Holmes et al., 1988) and are most closely related to the type species $O$. anthropi, as shown by phenotyping and 16S rDNA homology (Figs 1 and 2) and by the relatively strong DNA-DNA reassociation of about $50 \%$ (Table 3 ). Hence, they affiliate with Ochrobactrum at the generic level. The name Ochrobactrum tritici sp. nov. is proposed for REP group $\mathbf{J}$ strains since these strains were isolated from the rhizoplane of wheat (Triticum aestivum). Strain SCII $24^{T}$ is the type strain of Ochrobactrum tritici $\mathrm{sp}$. nov. Characteristic features of $O$. tritici are described below.

EMBL sequence X54743 of 'Solomonas fluorantheni' (not shown) was placed within the cluster collection of core Ochrobactrum spp. (excluding $O$. intermedium). It is suggested therefore that the taxonomic position of this organism is re-examined.

\section{Description of Ochrobactrum grignonense sp. nov.}

Ochrobactrum grignonense (gri.gno.nen'se. French n. Grignon a location in France; L. neut. suffix -ense indicating provenance; N.L. neut. adj. grignonense pertaining to Grignon, region from which the strains were isolated).

Cells are Gram-negative (aminopeptidase-positive), aerobic (oxidase- and catalase-positive), pleomorphic short rods $(0.6-1.2 \times 0.4 \mu \mathrm{m})$ and highly motile by subpolar or peritrichous flagella. Grows between 4 and $40{ }^{\circ} \mathrm{C}$ (optimum $30^{\circ} \mathrm{C}$ ) and between $\mathrm{pH}$ values of 3 and 9 (optimum $\mathrm{pH}$ 6-7). Colonies are circular, isolated, entire, low convex, smooth, milky-opaque and about $1 \mathrm{~mm}$ in diameter after incubation for $24 \mathrm{~h}$ on NA. No colony pigment development was observed. Able to utilize (oxidize) 68 of 95 carbon sources of BIOLOG-GN microtitre plates and showed positive reactions in 6 of 22 tests and in 8 of 20 tests in the API 20E and API 20NE systems, respectively. Resistant to polymyxin B and colistin. Within the genus Ochrobactrum, the following characters were 
of unique diagnostic value for $O$. grignonense: (i) BIOLOG-GN: utilization of malonic acid and no utilization of adonitol or D-glucosaminic acid; (ii) API 20E: acid production from melibiose and arabinose (48 h); (iii) API 20NE: assimilation of mannose (24 h) and no assimilation of maltose (48 h). In addition, 23 other phenotypic characters were identified by which $O$. grignonense can be differentiated from $O$. anthropi, $O$. intermedium and $O$. tritici. At the genome level, $O$. grignonense is clearly different from other Ochrobactrum species in composition of total DNA and 16S rDNA. O. grignonense DNA has a $\mathrm{G}+\mathrm{C}$ content of $58 \mathrm{~mol} \%$. The type strain of $O$. grignonense, strain OgA9 $\mathrm{a}^{\mathrm{T}}$, was deposited in BCCM/LMG and DSMZ culture collections as LMG $18954^{\mathrm{T}}$ and DSM $13338^{\mathrm{T}}$, respectively; similarly the $O$. grignonense reference strain OgA9c was deposited as LMG 18955 and DSM 13339.

\section{Description of Ochrobactrum tritici sp. nov.}

Ochrobactrum tritici (tri'ti.ci. M.L. gen. n. tritici from Triticum, generic name for wheat, from which the strains were isolated).

Cells are Gram-negative (aminopeptidase-positive), aerobic (oxidase- and catalase-positive), pleomorphic short rods $(0.6-1.4 \times 0.4-0.6 \mu \mathrm{m})$ and highly motile by subpolar or peritrichous flagella. Grows between 4 and $40{ }^{\circ} \mathrm{C}$ (optimum $30^{\circ} \mathrm{C}$ ) and between $\mathrm{pH}$ values of 3 and 9 (optimum pH 6-pH 7). Colonies are opaque and mucoid and quickly become confluent during incubation on NA. No colony pigment development was observed. Able to utilize (oxidize) 62 of 95 carbon sources of BIOLOG-GN microtitre plates and showed positive reactions in 4 of 22 tests and in 10 of 20 tests of API 20E and API 20NE systems, respectively. Susceptible to polymyxin B and colistin. Within the genus Ochrobactrum, the following characters were of unique diagnostic value for $O$. tritici: (i) BIOLOGGN : utilization of sebacic acid and no utilization of $\gamma$ hydroxybutyric acid; (ii) API 20NE: assimilation of gluconate $(48 \mathrm{~h})$. In addition, 24 other phenotypic characters were identified by which $O$. tritici can be differentiated from $O$. anthropi, $O$. intermedium and $O$. grignonense. At the genome level, $O$. tritici is clearly different from other Ochrobactrum species in total DNA composition. $O$. tritici is separated from $O$. intermedium and $O$. grignonense by sequence heterogeneity of $16 \mathrm{~S}$ rDNA, but delineation from $O$. anthropi by $16 \mathrm{~S}$ rDNA heterogeneity is not significant. $O$. tritici DNA has a $\mathrm{G}+\mathrm{C}$ content of $59 \mathrm{~mol} \%$. The type strain of O. tritici, strain SCII $24^{\mathrm{T}}$, was deposited in BCCM/ LMG and DSMZ culture collections as LMG $18957^{\mathrm{T}}$ and DSM $13340^{\mathrm{T}}$, respectively; similarly the $O$. tritici reference strain LAIII106 was deposited as LMG 18958 and LMG 13341.

\section{ACKNOWLEDGEMENTS}

This study was supported by a grant from the OECD to M. L., and parts of this work were supported by the Deutsche Forschungsgemeinschaft, project Ha1708/2. We are grateful to Dr R. Christen for helpful discussions and suggestions on phylogenetic analyses. We thank Dr H. Claus for providing electron microscopy photos of $O$. grignonense $\mathrm{OgA} 9 \mathrm{a}^{\mathrm{T}}$ and O. tritici SCII $24^{\mathrm{T}}$, and M. Bourrain for technical support in sequencing.

\section{REFERENCES}

Achouak, W., Christen, R., Barakat, M., Martel, M.-H. \& Heulin, T. (1999). Burkholderia caribensis sp. nov., an exopolysaccharideproducing bacterium isolated from vertisol microaggregates in Martinique. Int J Syst Bacteriol 49, 787-794.

Aguillera, M. M., Hodge, N. C., Stall, R. E. \& Smart, G. C., Jr (1993). Bacterial symbionts of Steinernema scapterisci. J Invertebr Pathol 68, 68-72.

Anderson, R. D., Bao, C.-Y., Minnick, D. T., Veigel, M. \& Sedwick, W. D. (1992). Optimization of double-stranded DNA sequencing for polymerase chain reaction products. USB Editorial Comments 19, 39-40, 57-58.

Atlas, R. M. (1995). Handbook of Media for Environmental Microbiology. Boca Raton, FL: CRC Press.

Barriuso, E. \& Houot, S. (1996). Rapid mineralization of the Striazine ring of atrazine in soils in relation to soil management. Soil Biol Biochem 28, 1341-1348.

Bauer, A. W., Kirby, W. M. M., Sherris, J. C. \& Turck, M. (1966). Antibiotic susceptibility testing by a standardized single disk method. Am J Clin Pathol 45, 493-496.

Biebel, A., Schloter, M., Kirchhof, G. \& Hartmann, A. (1995). Enrichment of soil bacteria with magnetic and nonmagnetic immunological methods and identification using Inter-LINE PCR and genomic fingerprinting. In Proceedings of the International Symposium 'Exploration of Microbial Diversity, Ecological Basis and Biotechnical Utility', June 12-15, 1995, Goslar, Germany, p. 25.

Brenner, D. J., McWorter, A. C., Leete Knutson, J. K. \& Steigerwalt, A. G. (1982). Escherichia vulneris: a new species of Enterobacteriaceae associated with human wounds. J Clin Microbiol 15, 1133-1140.

Cashion, P., Holder-Franklin, M. A., McCully, J. \& Franklin, M. (1977). A rapid method for the base ratio determination of bacterial DNA. Anal Biochem 81, 461-466.

Crosa, J. M., Brenner, D. J. \& Falkow, S. (1973). Use of a singlestrand specific nuclease for analysis of bacterial and plasmid deoxyribonucleic acid homo- and hetero-duplexes. J Bacteriol 115, 904-911.

De Ley, J. (1992). The proteobacteria: ribosomal RNA cistron similarities and bacterial taxonomy. In The Prokaryotes, 2nd edn, pp. 2111-2140. Edited by A. Balows, H. G. Trüper, M. Dworkin, W. Harder \& K.-H. Schleifer. New York: Springer.

De Ley, J., Mannheim, W., Segers, P., Lievens, A., Denjin, M., Vanhoucke, M. \& Gillis, M. (1987). Ribosomal ribonucleic acid cistron similarities and taxonomic neighborhood of Brucella and CDC group Vd. Int J Syst Bacteriol 37, 35-42.

Garland, J. L. \& Mills, A. L. (1991). Classification and characterisation of heterotrophic microbial communities on the basis of patterns of community-level sole-carbon-source utilization. Appl Environ Microbiol 57, 2351-2359.

Grimont, P. A. D., Popoff, M. Y., Grimont, F., Coynault, C. \& Lemelin, M. (1980). Reproducibility and correlation study of three deoxyribonucleic acid hybridisation procedures. Curr Microbiol 4, 325-330. 
Gutell, R. R., Larsen, N. \& Woese, C. R. (1994). Lessons from an evolving rRNA: $16 \mathrm{~S}$ and $23 \mathrm{~S}$ rRNA structures from a comparative perspective. Microbiol Rev 58, 10-26.

Holmes, B., Popoff, M., Kiredjian, M. \& Kersters, K. (1988). Ochrobactrum anthropi gen. nov., sp. nov. from human clinical specimens and previously known as group Vd. Int $J$ Syst Bacteriol 38, 406-416.

Kimura, M. (1980). A simple method for estimating evolutionary rates of base substitutions through comparative studies of nucleotide sequences. J Mol Evol 16, 111-120.

Jumas-Bilak, E., Michaux-Charachon, S., Bourg, G., Ramuz, M. \& Allardet-Servent, A. (1998). Unconventional genomic organisation in the alpha subgroup of the Proteobacteria. J Bacteriol 180, 2749-2755.

Lebuhn, M., Schloter, M., Hartmann, A., Achouak, W., Berge, O. \& Heulin, T. (1997). Investigations on Ochrobactrum species in soil and in the wheat rhizosphere. Colloque Rhizosphère Aix '97, p. 63. SFM Phytopathologie.

Louws, F. J., Schneider, M. \& de Bruijn, F. J. (1996). Assessing genetic diversity of microbes using repetitive sequence-based PCR (rep-PCR). In Nucleic Acid Amplification Methods for the Analysis of Environmental Samples, pp. 63-94. Edited by G. Toranzos. Lancaster, PA: Technomic Publishing.

McInroy, J. A. \& Kloepper, J. W. (1994). Novel bacterial taxa inhabiting internal tissues of sweet corn and cotton. In Improving Plant Productivity with Rhizosphere Bacteria, p. 190. Edited by M. H. Ryder, P. M. Stephens \& G. D. Bowen. Adelaide: CSIRO.

Marchesi, J. R., Sato, T., Weightman, A. J., Martin, T. A., Fry, J. C., Hiom, S. J. \& Wade, W. G. (1998). Design and evaluation of useful bacterium-specific PCR primers that amplify genes coding for bacterial 16S rRNA. Appl Environ Microbiol 64, 795-799.

Mesbah, M., Premachandran, U. \& Whitman, W. B. (1989). Precise measurement of the $\mathrm{G}+\mathrm{C}$ content of deoxyribonucleic acid by high-performance liquid chromatography. Int $J$ Syst Bacteriol 39, 159-167.

Moreno, E. (1992). Evolution of Brucella. In Advances in Brucellosis Research, pp. 198-218. Edited by M. Plommet. Wageningen: Pudoc Scientific Publishers.

Moreno, E. (1997). In search of a bacterial species definition. Rev Biol Trop 45, 753-771.

Moyer, N. P. \& Hausler, W. J., Jr (1992). The genus Brucella. In The Prokaryotes, 2nd edn, pp. 2384-2400. Edited by A. Balows, H. G. Trüper, M. Dworkin, W. Harder \& K.-H. Schleifer. New York: Springer.

Ruimy, R., Breittmayer, V., Elbaze, P., Lafaye, B., Boussemart, O., Gauthier, M. \& Christen, R. (1994). Phylogenetic analysis and assessment of the genera Vibrio, Photobacterium, Aeromonas, and Plesiomonas deduced from small-subunit rRNA sequences. Int J Syst Bacteriol 44, 416-426.

Saitou, N. \& Nei, M. (1987). The neighbor-joining method: a new method for reconstructing phylogenetic trees. Mol Biol Evol 4, 406-425.

Sato, K. \& Jiang, J.-Y. (1996). Gram-negative bacterial flora on the root surface of wheat (Triticum aestivum) grown under different soil conditions. Biol Fertil Soils 23, 273-281.

Schloter, M., Aßmus, B. \& Hartmann, A. (1995). The use of immunological methods to detect and identify bacteria in the environment. Biotechnol Adv 13, 75-90.

Schloter, M., Melzl, H., Alber, T. \& Hartmann, A. (1996). Diversität von Ochrobactrum anthropi-Populationen in landwirtschaftlichen Böden. Mitt Dtsch Bodenkundl Ges 81, 57-60.

Sneath, P. H. A. (1993). Evidence from Aeromonas for genetic crossing-over in ribosomal sequences. Int $J$ Syst Bacteriol 43, 626-629.

Stackebrandt, E. \& Goebel, B. M. (1994). Taxonomic note: a place for DNA-DNA reassociation and 16S rRNA sequence analysis in the present species definition in bacteriology. Int $J$ Syst Bacteriol 44, 846-849.

Strimmer, K. \& Von Haeseler, A. (1996). Quartet puzzling: a quartet maximum-likelihood method for reconstructing tree topologies. Mol Biol Evol 13, 964-969.

Strunk, O. \& Ludwig, W. (1996). ARB : a software environment for sequence data. Technische Universität München, Munich, Germany.

Swings, J., Lambert, B., Kersters, K. \& Holmes, B. (1992). The genera Phyllobacterium and Ochrobactrum. In The Prokaryotes, 2nd edn, pp. 2601-2604. Edited by A. Balows, H. G. Trüper, M. Dworkin, W. Harder \& K.-H. Schleifer. New York: Springer.

Vandamme, P., Pot, B., Gillis, M., de Vos, P., Kersters, K. \& Swings, J. (1996). Polyphasic taxonomy, a consensus approach to bacterial systematics. Microbiol Rev 60, 407-438.

Velasco, J., Romero, C., López-Goñi, I., Leiva, J., Díaz, R. \& Moriyòn, I. (1998). Evaluation of the relatedness of Brucella spp. and Ochrobactrum anthropi and description of Ochrobactrum intermedium sp. nov., a new species with a closer relationship to Brucella spp. Int J Syst Bacteriol 48, 759-768.

Versalovic, J., Schneider, M., de Bruijn, F. J. \& Lupski, J. R. (1994). Genomic fingerprinting of bacteria using repetitive sequencebased polymerase chain reaction. Methods Mol Cell Biol 5, 25-40.

Weisburg, W. G., Barns, S. M., Pelletier, D. A. \& Lane, D. J. (1991). $16 \mathrm{~S}$ ribosomal amplification for phylogenic study. J Bacteriol 173, 697-703.

Yanagi, M. \& Yamasato, K. (1993). Phylogenetic analysis of the family Rhizobiaceae and related bacteria by sequencing of $16 \mathrm{~S}$ rRNA gene using PCR and DNA sequencer. FEMS Microbiol Lett 107, 115-120. 